\title{
Structures in Shallow Marine Sediments Associated with Gas and Fluid Migration
}

\author{
Gongzheng Ma ${ }^{1,2}$, Linsen Zhan ${ }^{2,3}$, Hailong Lu ${ }^{1,2, *}$ and Guiting Hou ${ }^{1, *}$ \\ 1 School of Earth and Space Sciences, Peking University, Beijing 100871, China; 1601110593@pku.edu.cn \\ 2 Beijing International Center for Gas Hydrate, Peking University, Beijing 100871, China; zhanlinsen@163.com \\ 3 College of Engineering, Peking University, Beijing 100871, China \\ * Correspondence: hlu@pku.edu.cn (H.L.); gthou@pku.edu.cn (G.H.)
}

Citation: Ma, G.; Zhan, L.; Lu, H.; Hou, G. Structures in Shallow Marine Sediments Associated with Gas and Fluid Migration. J. Mar. Sci. Eng. 2021, 9, 396. https://doi.org/10.3390/ jmse 9040396

Academic Editor: Antoni Calafat

Received: 13 March 2021

Accepted: 6 April 2021

Published: 8 April 2021

Publisher's Note: MDPI stays neutral with regard to jurisdictional claims in published maps and institutional affiliations.

Copyright: (c) 2021 by the authors. Licensee MDPI, Basel, Switzerland. This article is an open access article distributed under the terms and conditions of the Creative Commons Attribution (CC BY) license (https:/ / creativecommons.org/licenses/by/ $4.0 /)$.

\begin{abstract}
Geological structure changes, including deformations and ruptures, developed in shallow marine sediments are well recognized but were not systematically reviewed in previous studies. These structures, generally developed at a depth less than $1000 \mathrm{~m}$ below seafloor, are considered to play a significant role in the migration, accumulation, and emission of hydrocarbon gases and fluids, and the formation of gas hydrates, and they are also taken as critical factors affecting carbon balance in the marine environment. In this review, these structures in shallow marine sediments are classified into overpressure-associated structures, diapir structures and sediment ruptures based on their geometric characteristics and formation mechanisms. Seepages, pockmarks and gas pipes are the structures associated with overpressure, which are generally induced by gas/fluid pressure changes related to gas and/or fluid accumulation, migration and emission. The mud diapir and salt diapir are diapir structures driven by gravity slides, gravity spread and differential compaction. Landslides, polygonal faults and tectonic faults are sediment ruptures, which are developed by gravity, compaction forces and tectonic forces, respectively. Their formation mechanisms can be attributed to sediment diagenesis, compaction and tectonic activities. The relationships between the different structures, between structures and gas hydrates and between structures and authigenic carbonate are also discussed.
\end{abstract}

Keywords: shallow marine structures; cold seep; pockmark; gas chimney; mud volcano; polygonal fault

\section{Introduction}

Shallow marine structures are sediment deformations and ruptures developed in a shallow environment less than $1000 \mathrm{~m}$ below the seafloor (mbsf) due to many kinds of driving forces such as overpressure, differential gravity, compaction forces, tectonic forces, etc. Berton and Vesely [1] identified comet pockmarks on acoustic profiles and suggested that they are formed by gas flows and modified by the bottom currents. Shakhova et al. [2] detected pockmarks using multi-beam sonar backscatter data and proposed that gas release causes the pockmarks. Chen et al. [3] identified gas chimneys on seismic profiles and indicated that they are related to thermogenic gas migration. Matsumoto et al. [4] identified gas pipes on seismic profiles and suggested that they are induced by thermogenic gas migration. Chen et al. [5] identified mud diapirs and mud volcanoes on seismic profiles and indicated that their formation mechanisms are related to an ample discharge of gasbearing fluids. Ho et al. [6] studied the morphology of pipe structures and polygonal faults and suggested that they are formed by overpressured gases and fluids. Previous studies show that shallow marine structures are generally considered as pathways for gas and fluid migration. In recent years, the structures related to gas hydrate accumulation have increasingly attracted researchers' attention.

Gas hydrates have been intensively studied as a potential clean energy source in the last decades [7-9]. They are stable under relatively low temperature and high pressure 
conditions, and are generally located in sediments several hundred meters deep or even deeper below the seafloor [10-13]. Massive gas hydrate dissociation can release vast amounts of methane into seawater and enhance ocean acidification, which is a significant process affecting the carbon balance in the marine environment [14-16]. The accumulation and distribution of gas hydrates are closely related to the gas and fluid migration which is primarily controlled by the structures in shallow marine sediments [17-21]. Wang et al. [22] studied three cold seeps in the Taixinan Basin and found massive gas hydrate and chimney structures associated with these cold seeps. Lu et al. [23] studied a mature pockmark in the Zhongjiannan Basin and indicated that the pockmark creation was induced by methane consumption. Natalia and Soledad [24] recognized gassy sediments, pockmarks and gas plumes in the Ria de Vigo in Spain and indicated that the underlying gassy sediments are the gas sources of the pockmarks. Berton and Vesely [1] identified mud volcanoes and underlying chimney structures on the continental margin of southeastern Brazil.They suggested that gas seeps occur along with the chimney structures. Taylor et al. [25] recognized salt diapirs and associated faults at the Blake Ridge Diapir, indicating that the gas and fluid might migrate upward through these faults. Lastras et al. [26] recognized shallow slides and pockmarks in the Eivissa Channel and suggested that the pockmarks occur near the slide headwall scars that reveal fluid escaping. Alrefaee et al. [27] studied polygonal faults and associated fluid migration in the Northern Carnarvon Basin and indicated that the polygonal fault systems can act as pathways for the fluid migration. Gasperini et al. [28] studied the tectonic fault in the Sea of Marmara and suggested that gas and fluid emissions increase along the tectonic fault system after an earthquake.

As introduced above, these structures are closely related to each other, and the structures are closely associated with gas and fluid migration. However, the characteristics, formation mechanisms and effect of the structures are not systematically reviewed. This article aims to provide a systematic summary of the current knowledge about the shallow structures developed in shallow sediments, to classify the shallow marine structures, identify their characteristics and explore the mechanisms of the structures, and discuss their relationships with gas and fluid migration.

\section{The Classification of the Structures}

The structures are generally driven by different geological forces, including overpressure, gravity, compaction forces and tectonic forces.

Overpressure is widely developed in many hydrocarbon basins, and its building, transfer, and release generally induce different structures. A seepage occurs during the overpressure release (Figure 1A), a gas chimney develops during the overpressure building and transfer (Figure 1C), and a pockmark is a seafloor mark of the overpressure release site (Figure 1B). Therefore, seepages, pockmarks and gas chimneys are classified as overpressure-associated structures. Seepage may be referred to as a natural phenomenon rather than a geological structure. However, seepage is an active gas and fluid release process, and the gas chimney indicates the process of gas and fluid accumulation and migration; they make up an integrated overpressure system. Therefore, the seepage is classified as an overpressure-associated structure.

Diapir structures are soft-sediment deformations driven by differential gravity and compaction [29-32]. The soft plastic layers such as mud layers and salt layers easily extrude into overlying layers because of differential forces. Therefore, the mud diapir (Figure 1D) and the salt diapir (Figure 1E) are classified as diapir structures. The mud volcano and mud mound are also included in shallow marine structures in this study. The overpressure of the gas- and fluid-rich mud sediment is a critical driving force for their formation. In this study, we classify mud volcanoes and mud mounds as mud diapirs. The two structures are regarded as the later stage of the mud diapir. When the mud diapir reaches the seafloor, a conic-like structure formed is termed a mud volcano, and a dome-like structure is termed a mud mound. 


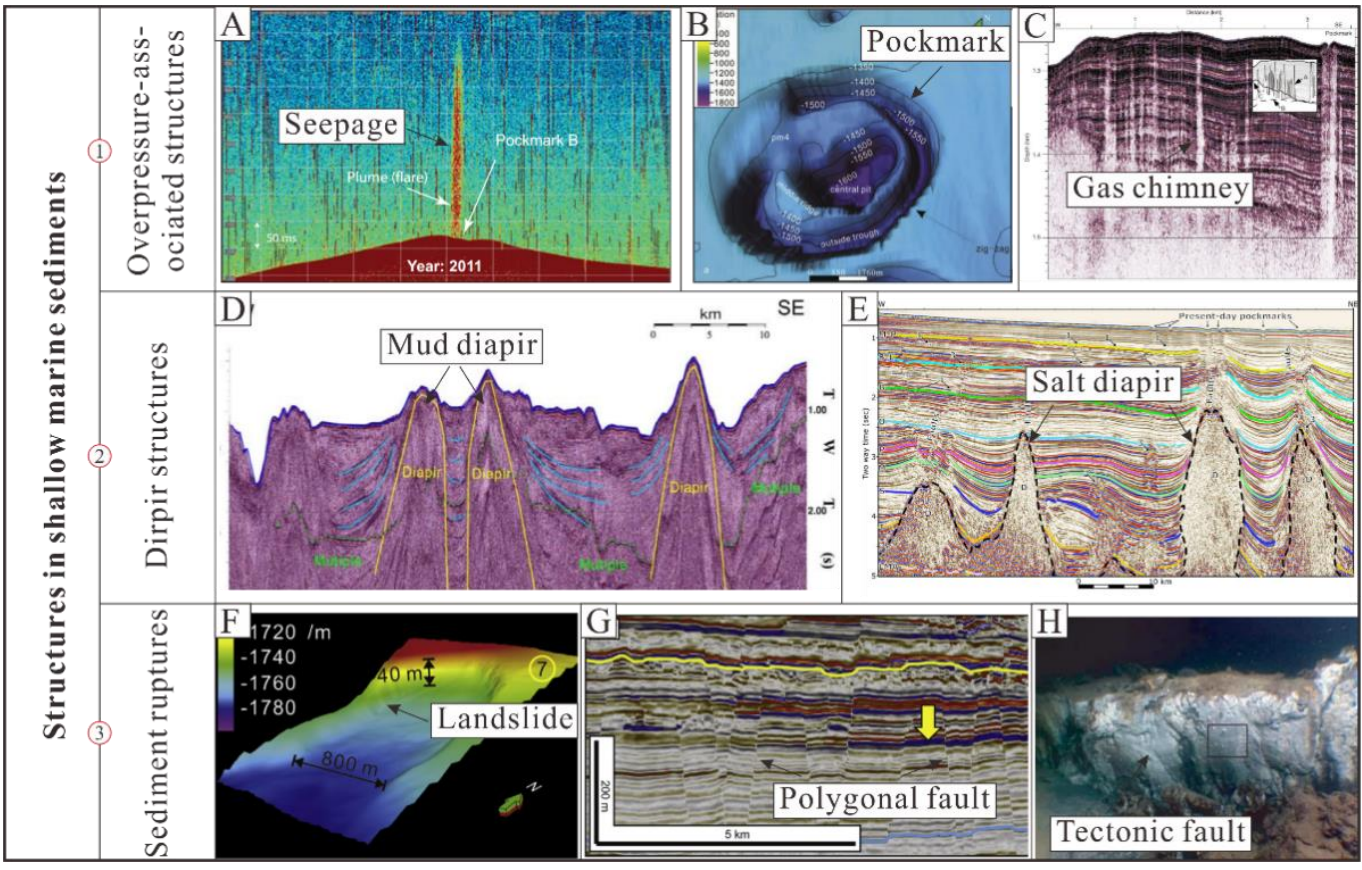

Figure 1. The classification of the structures developed in shallow marine sediments. (A) Seepage from bathymetry image, Vestnesa Ridge, west Svalbard margin, Norway (modified from Goswami et al. [33]); (B) Pockmark from bathymetry image, Zhongjiannan Basin, western margin of the South China Sea, China (modified from Lu et al. [23]); (C) Gas chimney from the seismic image, Cascadia margin, off the coast of Vancouver Island, Canada (modified from Wood et al. [34]); (D) Mud diapir from the seismic image, Lower Fangliao Basin, offshore SW Taiwan (modified from Hsu et al. [35]); (E) Salt diapir from the seismic image, upper Atlantic margin, SE Brazil (modified from de Mahiques et al. [36]); (F) Landslide from bathymetry image, Pearl River Mouth Basin, the northern slope of South China Sea (modified from Chen et al. [3]); (G) Polygonal fault from the seismic image, offshore Uruguay (modified from Turrini et al. [37]); (H) Tectonic fault from the sea-bottom picture, Tekirdag Basin, Sea of Marmara (modified from Armijo et al. [38]).

Landslides (Figure 1F), polygonal faults (Figure 1G), and tectonic faults (Figure $1 \mathrm{H})$ are driven by gravity, compaction forces and tectonic forces, respectively. All these structures have one or multiple prominent rupture surfaces; therefore, they are classified as sediment ruptures. The structural characteristics are usually different because they are not driven by a single force. The rupture surface is a reasonable connection that strings together the landslide, the polygonal fault, and the tectonic fault. In addition, the "shallow marine structure" is not restricted to a depth of less than $1000 \mathrm{mbsf}$ due to the following considerations. First, the shallow marine structures are generally distributed in shallow unconsolidated marine sediments. Their structural characteristics are various and are easily influenced by many unpredictable factors. Second, some structures are developed in shallow and deep environments, and some structures are developed in a deep environment but extend into a shallow environment.

\section{Overpressure-Associated Structure}

Overpressure is generally induced by hydrocarbon generation, differential compaction, hydrothermal pressurization, clay mineral dehydration, and tectonic compaction [39]. The combination of temperature changes, pressure drop from water unloading, rapid burial by salt deposition, pressure increases during the following water loading, and relative sea level-rise play a fundamental role in overpressure development and release in the underlying evaporites sediments [40-44]. During the overpressure building, transfer, and release, the gas and fluid accumulation, migration, and release generally occur, resulting in pore pressure changes and associated structures $[45,46]$. 


\subsection{Seepage}

Marine seepages, also called "methane seeps" and "cold seeps", are active structures on the seafloor caused by gas and fluid release (Figure 2A). These structures were first reported in 1958 [28]. A seepage system generally consists of a gas and fluid source, a pipelike pathway and a leaking structure [47]. Seepages are recognized as gas flares/flames on bathymetry image and as gas bubbles in sea-bottom photographs and they are widely found in the South China Sea, the Gulf of Mexico, off the Costa Rica shore, off Svalbard in Norway, the Hydrate Ridge of America, off the shores of Ireland and New Zealand, the eastern Black Sea, the eastern Mediterranean, and the Cascadia margin [13,22,42,48-54]. A gas flare as high as $750 \mathrm{~m}$ was reported in offshore NW-Svalbard [55], and numerous gas bubbles were reported in the northern South China Sea [56]. Seepages are generally distributed over marine or lacustrine hydrocarbon sediment basins [57] and are possibly related to salt diapirs and tectonic faults [57-59]. In addition, seepage is considered as the previous stage of pockmarks since active seepages are widely discovered above pockmarks $[60,61]$.

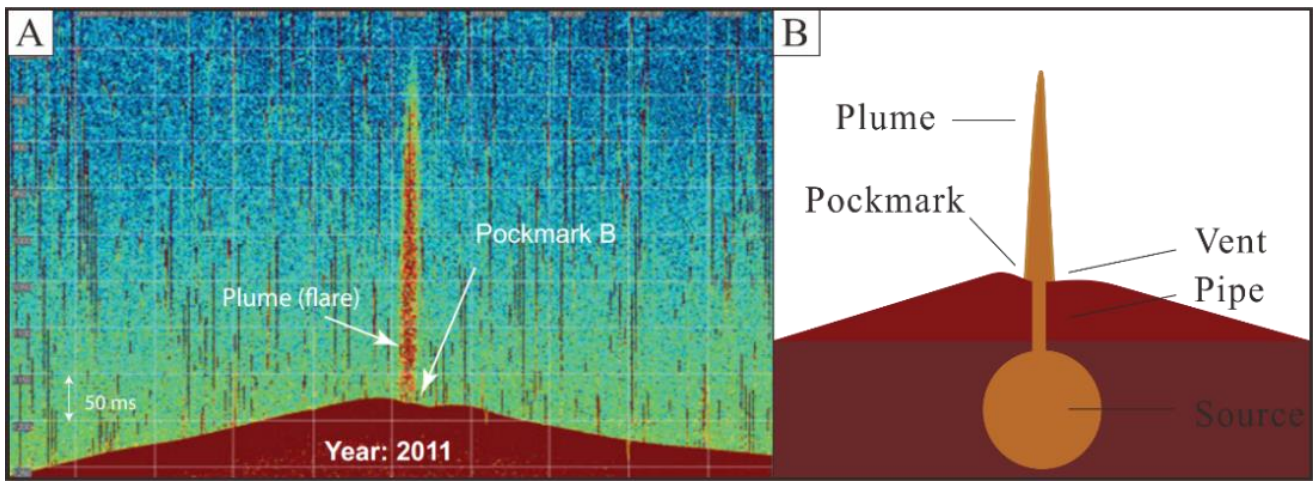

Figure 2. The (A) acoustic characteristics (modified from Goswami et al. [33]) and (B) descriptive mechanism of seepage.

The gas sources of seepages are generally composed of deep thermogenic gas and shallow biogenic gas [28,62-66]. Deep thermogenic gas migrates upward from a deep source layer along the interface between a salt diapir and the surrounding sediments and the fault plane of an active fault $[28,67,68]$. When gases and fluids migrate through the evaporite layer, salt dissolves in the fluid and is transported to the seafloor. The density of the salt-rich fluid is higher than that of seawater; as a result, the salt-rich fluid deposits around the leaking site, and then forms a brine pool $[40,67,69,70]$. Shallow biogenic gas migrates upward through gas pipes to form a seepage [64]. The driving force of the seepage is considered to be overpressure, and the overpressure is generally induced by the continuous accumulation of gases and fluids. In the Hydrate Ridge, the accumulated gas and fluid in shallow layers opens micro-fractures to migrate through $[51,58,71-73]$. In the Cascadia subduction zone, methane seepage was induced by the collision between ocean crust plates [74].

In addition, gas hydrate and authigenic carbonate possibly exist as trap layers resulting in gas and fluid accumulation and overpressure development. The seepage intensity is supposed to be dominated by the pressure of the accumulated gas and fluid. High gas pressure induces strong gas ejection flares on the seafloor, up to $750 \mathrm{~m}$ high $[55,75,76]$. Therefore, trap sealing is supposed to cause overpressure development and eruption [77]. During overpressure eruption, the gas hydrate mass and authigenic carbonate mass are blown out to the seafloor and form the gas hydrate outcrops and carbonate stacks, respectively $[68,70,78-81]$. Seepages are discovered along with the fractures in the carbonate reef, indicating that the fractures exist as the pathway for seepages [58,82]. In the north Gulf of Mexico, carbonate crusts gradually form in the sediment sealing the seepage simultaneously [83]. The authigenic carbonates are different from the autochthonous carbonates, 
which were deposited in shallow-water environments and transported to the outer shelf due to the gravitational collapse of the platform margin [45].

The overpressure is the primary driving force to form a seepage. A strong overpressure leads to a vigorous seepage, and a weak overpressure leads to a gentle seepage. Seepage is a part of the overpressure-associated system that occurs during the overpressure release. The system is also composed of a source and a pipe structure during the overpressure accumulation and transfer, respectively (Figure 2B).

Geochemical analysis of the sediment samples, pore water, and gas bubbles collected in the seepage areas indicate that the gas hydrate disassociation probably provides the seepage gas source $[63,64,84,85]$. In the Taixinan basin in the South China Sea, newle formed seepages are discovered next to paleo-seepage sites. Gas hydrates formed in the paleo-seepage site seal the migration pathway of the gases and fluids. As a result, the gases and fluids migrate through a new pathway and leak from a new seepage site [22]. The cases indicate that seepages are considered significant indicators of gas hydrate reservoirs $[19,51,52,64,74,75]$. Geochemical analysis of the gas seepage can help estimate the gas source and determine whether the seepage is active or not $[48,65,85-87]$.

Authigenic carbonates are good markers of methane seepage and environmental conditions $[13,48,49,85,88,89]$, which generally exist as thick tight crusts and scattered multi-hole reefs $[13,90]$. The nodular high-Mg carbonate forms under low methane content conditions, and the aragonite carbonate crust forms under high methane or high Ca content conditions [48,82]. Microbial mats and benthos are discovered beside the active seepage $[38,60,74,82,91]$, related to anaerobic oxidation of methane and sulfate reduction $[48,79,82,92]$, which make a significant contribution to the formation of the authigenic carbonates.

Seepages are mostly discovered above pockmarks, with gentle or vigorous gas leakage, leaving crater-like depressions on the seafloor [90]. Gas pipes are also found below the seepages, considering as the pathways of gas and fluid migration [33]. In some cases, polygonal faults also exist as pathways for the seepages [20]. The structures show a close relationship with each other and the gas and fluid migration.

\subsection{Pockmarks}

Pockmarks are seafloor depressions firstly reported in the Emerald Basin in Canada [93]. Pockmarks are generally recognized as V- and U-shaped structures on acoustic profiles (Figure 3A) [1,62,84,94-101]. Pipe-like structures beneath pockmarks are usually discovered, indicating the migration of the gas and fluid, which can help to confirm if the pockmarks are active or not $[20,36,63,64,75,76,84,85,90,94,97,102-109]$.

Pockmarks are divided into three types based on their diameter, including unit pockmarks $(<10 \mathrm{~m})$, normal pockmarks $(10-1000 \mathrm{~m})$, and mega-pockmarks $(>1000 \mathrm{~m})[97,107]$. In map views, the pockmarks appear as circular, near-circular, elliptical, linear, and crescentic geometries $[23,36,99,110,111]$. In vertical views, pockmarks show as U-shapes, V-shapes and asymmetric shapes (Figure 3B) [67,78,104,109-119]. The nascent pockmark is possibly conic, modified by the bottom current, sliding activity, and pelagic sedimentation $[107,120]$. The mature pockmark is generally composed of an outer trough, a middle ridge, and a middle crater [23]. Regular and gentle gas and fluid flow usually lead to symmetrical and crater-like pockmarks; however, overpressure eruption and sediment collapse usually lead to asymmetry pockmarks (Figure 3) [84].

Pockmarks are seafloor marks generally induced by gas and fluid releases. In shallow marine sediments, continuous gas and fluid accumulation lead typically to a pore pressure increase. When the overpressure exceeds the limit of the overlying layers, the gases and fluids erupt into seawater, leaving a pockmark on the seafloor. The eruption model of gases and fluids was firstly proposed by Hovland [121] and is widely accepted by many researchers $[2,20,90,106,122]$. 


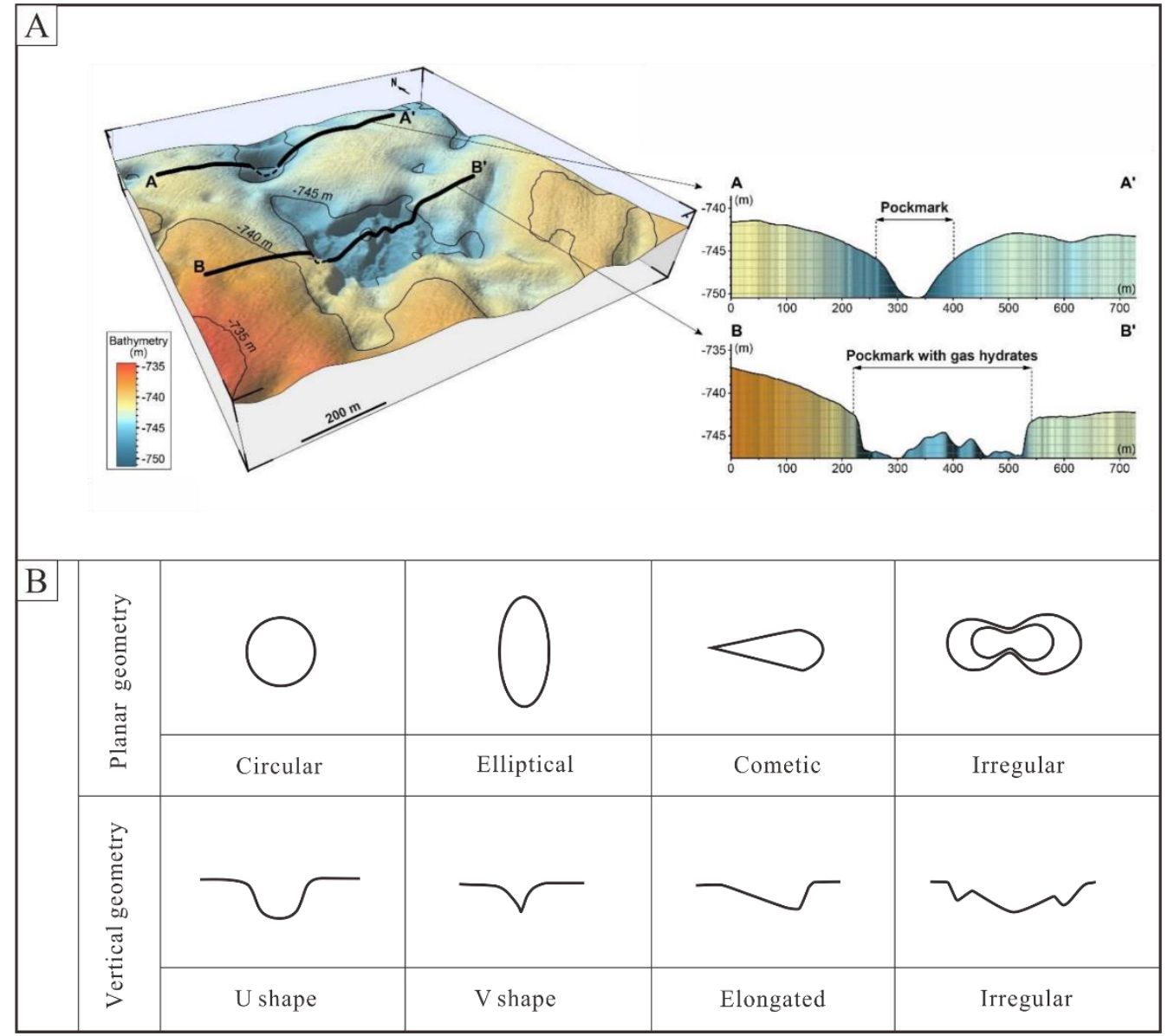

Figure 3. The (A) bathymetry characteristics (modified from Riboulot et al. [84]) and (B) schematic geometries (modified from Hovland [110]) of pockmark.

Many factors can lead to overpressure releases. Periodic sea level changes, glaciation and deglaciation, gas hydrate formation and disassociation, tidal and storm wave activity, rapid sedimentation and tectonic activity are supposed to break the balance between pore pressure and overburden pressure, inducing the leakage of the pore fluid and gas, leaving pockmarks on the seafloor $[59,63,98]$. Tidal cycles are considered the driving force of the gas and fluid accumulation and overpressure, and the overpressure eruption is triggered by storm waves $[98,105,117,121]$. Periodic sea level variation leads to the episodic eruption of the pore fluid and gas $[63,75,94,123,124]$. Meanwhile, overpressure eruption can be induced by deglaciation and earthquake activity $[59,100,122,125]$. In addition, a high sediment rate generally leads to overpressure. The sediment burial depth increases rapidly, causing a large amount of pore fluid in the sediment pore space, and the pore pressure increases quickly. The gas and fluid are driven along with the lithological interface, fault plane, and salt surface to release on the seafloor. In that case, pockmarks are prominent indicators of overpressure $[59,95,112]$.

Gas hydrate disassociation can be induced by sea level drops and deglaciation, and the process can lead to pockmark formations $[63,100]$. When hydrocarbon gases and fluids migrate upward to the gas hydrate stability zone (GHSZ), the gas hydrate forms to seal the migration pathway, and the free gas accumulates below the GHSZ to build overpressure. The gas, fluid, sediment, and gas hydrate are blown out to the seafloor when an overpressure eruption occurs and a pockmark forms [78]. Strong gas flares are widely discovered above pockmarks, which indicate that overpressure eruptions exist above the pockmarks $[13,33,54,55,64,68,76,105,126]$.

Carbonate ridges and stacks are found beside pockmarks, and many researchers have indicated that authigenic carbonates occur as trap layers, leading to overpressure 
eruptions [79,87]. The authigenic carbonates are considered as products related to methane oxidation and sulfate reduction [63] that are import indications of hydrocarbon gas and fluid migration. Geochemical analysis of the sediment samples, pore water, and carbonate from the pockmark area can help predict the gas and fluid sources $[85,90,98,100]$.

However, the gas and fluid flow in shallow marine sediments is still unclear because the process is hard to monitor [109]. Active pockmarks with an overlying active seepage and dormant pockmarks with an underlying gas pipe are widely discovered indicators of shallow gas accumulation $[107,118]$. Pockmarks are generally distributed above the hydrocarbon reservoir and fault system, indicating the location of the reservoir and migration pathway $[20,68,104,111,122,127-129]$.

\subsection{Gas Chimney}

Gas chimneys are also reported as "gas pipes" induced by gas and fluid percolation and migration in shallow marine sediments. The structures are generally considered as gas and fluid migration pathways. On seismic profiles, "gas plumes" or "gas clouds" are recognized as the indicators of gas pipes, which appear in a columnar geometry or a conic geometry (Figure 4A) [130]. According to the comprehensive literature investigation, the gas chimney geometries are divided into pipe-like, conic-like, corona-like, and cloud-like shapes (Figure 4B). Gas chimneys are supposed to be driven by adequate gas accumulation, composed of deep thermogenic gas and shallow biogenic gas [3]. Gas chimneys are recognized as acoustic blank zones, turbulent zones, ambiguous zones and pull-down reflections. The acoustic blank zone generally indicates gas-rich sediments [131], and the pull-down reflection possibly indicates free gas occurrence [132]. However, in other cases, researchers have recognized high amplitude pull-down reflections in the Lower Congo Basin. They interpreted them as stacked paleo-pockmarks [133], and the pull-up reflection can be induced by gas hydrate or carbonate occurrence [20].

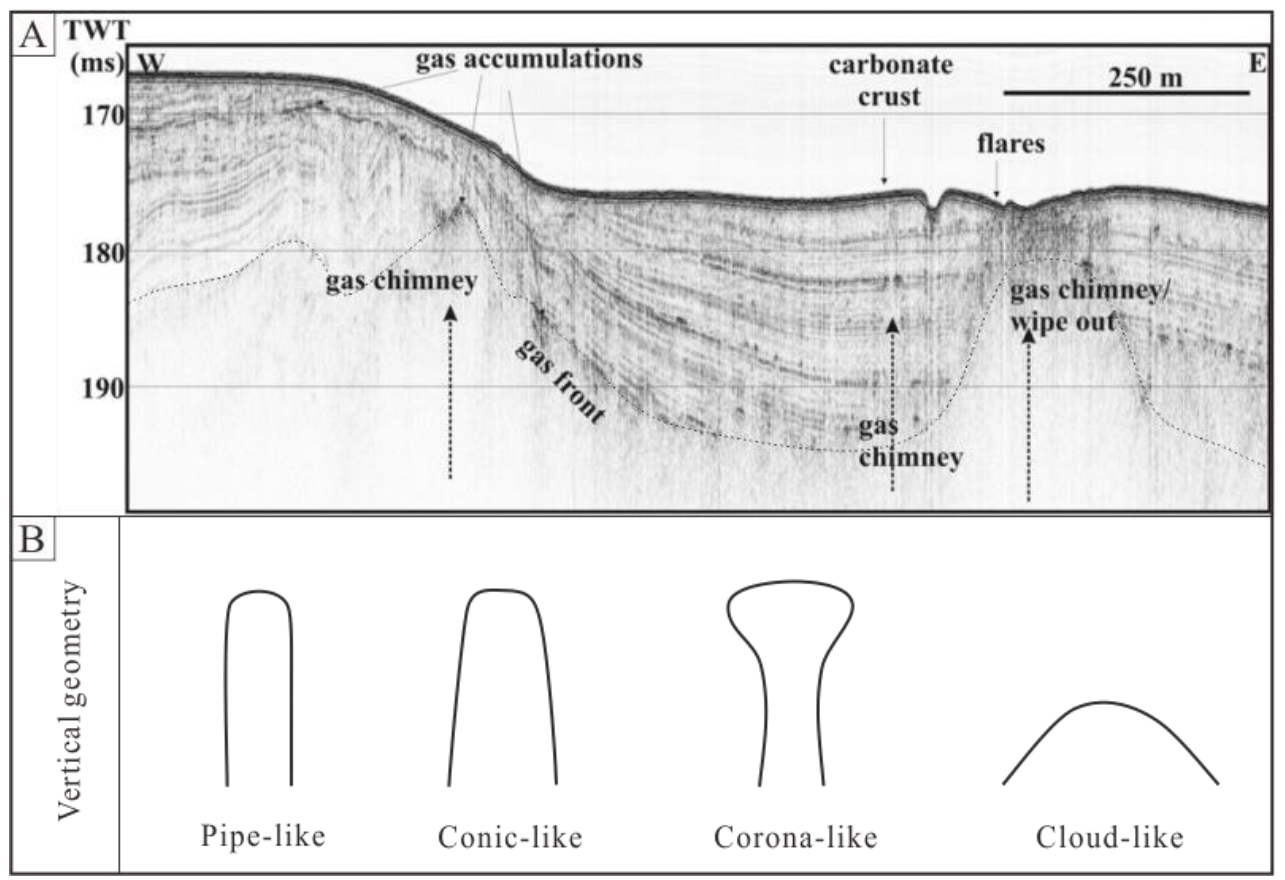

Figure 4. The (A) seismic characteristics (modified from Chand et al. [64]) and (B) schematic geometries of gas chimney.

Previous studies have proposed that free gas is supposed to be sealed by the capillary force of the sediments. When the overpressure exceeds the sealing force, free gas starts to migrate upward along the gas pipe. During the migration, the overlying pore fluid in the pipe is expelled out, and the underlying pore fluid is pumped into the pipe. When the 
gas releases into seawater, the underlying free gas is sealed again by the capillary force produced by the pore fluid in the gas pipe [103]. The process of gas migration and emission is episodic.

In offshore SW Taiwan, extensive gassy sediments exist [134], which indicate the gas migration in shallow marine sediments. Gas percolation generally induces gas accumulation and overpressure, which results in dome structures on the lithological interface. Continuous gas accumulation leads to overpressure increase and small fracture formation [50]. The gas migrates upward along the small faults and forms a gas chimney. The geometries of gas pipes are possibly related to the gas pressure and sediment lithology. The pipe-like gas chimney is inclined to form in high gas pressure conditions and muddy sediments, and the cloud-like gas chimney is inclined to form in low gas pressure conditions and sandy sediments (Figure 4B).

In many cases, the gas chimneys are located above the bottom simulating reflectors (BSRs), below the BSRs, and through the BSRs, which indicate a good relation with gas hydrates $[22,33,34,55,132,133,135]$. Gas pipes are also found below pockmarks and seepages, indicating vertical pathways for pockmarks and seepages [127]. The gas migrates upward along salt tectonic faults and forms gas pipes at the upper end of the faults. The gas and fluid then migrate to the seafloor through the gas pipes [20]. When the gas migrates along faults and accumulates below the GHSZ, small fractures form due to overpressure, and periodic earthquakes drive the gas release along with the fractures [125]. Therefore, gas chimneys are supposed to record the multi-active seepage controlled by earthquake activities [122]. Deep thermogenic gas migrates along the deep faults and forms gas pipes that extend to the seafloor in the central North Sea [64]. In the Lower Congo Basin, researchers have recognized gas pipes located above the triple junction of the polygonal faults, indicating a close relationship between them [65].

When a gas pipe extends through the GHSZ, gas hydrates then form in the pipes [20]. When the gas hydrates disassociate to free gas, the free gas then migrates upward to form a gas pipe $[13,136]$, therefore, gas pipes can help locate free gas reservoirs and the gas hydrate layers.

\section{Diapir Structures}

Mud and salt diapirs have been extensively studied previously. Mud and salt layers are soft plastic layers and are easily deformed by differential gravity and compaction forces. In many gas hydrate studies, the two structures are recognized and facilitate gas and fluid migration.

\subsection{Mud Diapirs}

Mud diapirs are also reported as "mud volcanos" in the Olimpi diapiric field in the Mediterranean Ridge [137-139] and as "mud mounds" in the mud volcano area in the Gulf of Cadiz [140] (Figure 5A). The structures are focused and widely studied regarding gas and fluid migration [141-143]. The mud layers (Figure 5(B1)) saturated with gas and fluid move upward and form diapirs along with fractures or faults (Figure 5(B2)). When they erupt on the seafloor, the gas and fluid escape into the seawater, leaving the muddy sediment deposited.The conic-like mud structures are termed mud volcanoes (Figure 5(B3)) [81,144,145]. The mud diapirs are considered as the previous stage of mud volcanoes, indicating that the overpressure exists in muddy sediments before the mud volcano eruption [134]. Mud diapirs are mainly recognized as dome-like structure on and beneath the seafloor $[12,18,146,147]$. A previous study proposed that the deep hydrocarbon fluid migrated upward with liquified muddy sediments, solid blocks and shallow biogenic gas, and then erupted on the seafloor [70]. The slope angle of the mud volcano is possibly related to the viscosity of the muddy sediment [5]. The mud volcano is recognized as the bull-eye shape in map views [83]. On the seismic profile, the up-warp diapir geometry is recognized as a mud diapir [35]. Mud volcano outcrops are observed in Azerbaijan, with a 
methane emission volume of as much as $800 \mathrm{~m}^{3}$ per year $[148,149]$. Similar outcrops are observed in Diglipur Island, India [150], northern Italy [151], and Indonesia [152].

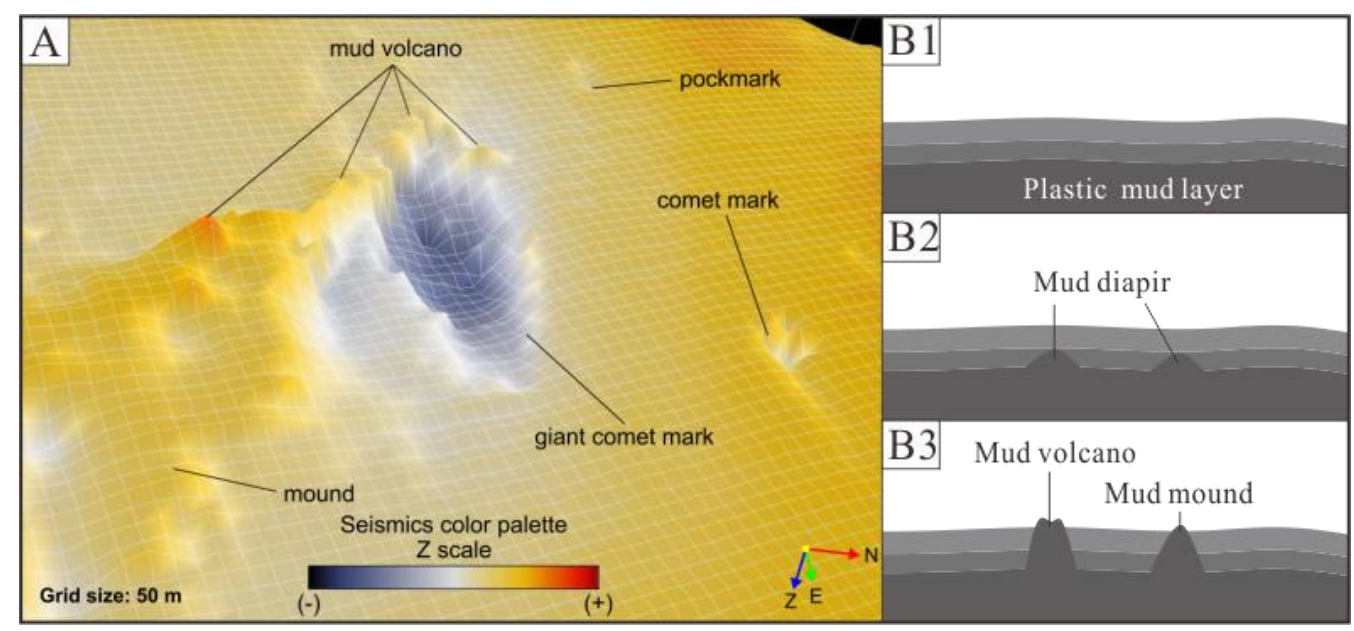

Figure 5. The (A) seismic characteristics (modified from Berton and Vesely [1]) and (B) descriptive mechanism of mud diapir/volcano/mound.

Previous researchers have proposed the following mud volcano formation mechanism. Firstly, the deep gas percolates upward to the upper plastic clay layer, and the pore spaces are filled with gas, resulting in gravity instability and sediment deformation [29]. Secondly, continuous gas accumulation induces a buoyancy increase, and a mud diapir initially forms in the weakness zone $[116,153]$. Thirdly, when the mud diapir extrudes into the seafloor, the gas and fluid eject into the seawater, and as muddy sediment is deposited around the ejection site, a mud volcano forms a conic-like shape [146].

The mud volcano formation is associated with the muddy sediment eruption $[1,134]$. Previous researchers found related evidence by AUV surveys in the Nile Deep Sea Fan [154]. Tectonic activity is supposed to be the primary trigger force driving the mud extrusion under the pre-condition of overpressure $[5,29,140,141,143,145,150]$. In other cases, the muddy flow driven by overpressure migrates upward through hydraulic fractures to form a mud volcano [130].

Deep heat flows are a possible driving force and fluid source for mud volcanoes [143]. In offshore SW Taiwan, heat flows are measured around the mud diapirs area. The results reveal that higher heat flow values exist above the mud diapirs, indicating that the heat flows migrate upward in the mud diapirs [155]. In the Barbados accretionary wedge, heat fluid roots from the underlying accretionary wedge or adjacent oceanic crust. With the temperature increase, the smectite-illite transformation is accelerated and releases quantities of water [156]. This process possibly promoted overpressure and undercompaction.

Periodic activities such as tectonic activity, overpressure, and heat flow eruption possibly result in biconic mud volcanoes. A buried mud volcano with biconic geometry was discovered in the South Caspian Basin. The South Caspian crust subducts into North Caspian crust, inducing the upper compressed mud layer migrates upward episodically, leading to the biconic geometry [157].

Gas hydrates are discovered within mud volcano areas, indicating that large quantities of methane gas and mud flow migrate upward to the shallow sediments [156]. When the gas and fluid migrate through the GHSZ, free gas is supposed to percolate into the surrounding sediments and form a gas hydrate [145]. Mud diapirs extrude through the gas hydrate zone, and this phenomenon is discovered in offshore Norway [158], the Barbados accretionary wedge [156], SW Taiwan [35,134], and the Indian Andaman islands [150], which show a good relationship between mud volcanos and gas hydrates. The gas and fluid flow are also identified above the mud diapirs. 
Brine pools are discovered located on the mud volcanoes in the Mediterranean Ridge, indicating salt occurrence $[69,70,159]$. When a mud flow migrates through a salt layer the salt dissolves in the fluid and migrates to the seafloor. Due to its larger density, salt-rich fluid deposits in a crater created by the mud volcano and forms a brine pool. Authigenic carbonate is found around the brine pool, indicating that the hydrocarbon gas and fluid possibly share the mud volcano pathways [70]. Carbonate outcrops are observed in the Nile Deep Sea Fan [154] and eastern Mediterranean mud volcanoes [160]. Carbonate chimneys filled with soft clay in the pipes are discovered in the South China Sea [82] and Mediterranean Ridge [70], indicating that the carbonate forms during the upward migrations of the soft clay.

\subsection{Salt Diapirs}

Salt diapirs is salt tectonics forms that generally present an up-warp geometry caused by the inherent instability of the salt (Figure 6A). Salt is mostly composed of halite which may contain various amounts of evaporites [161]. Salt layers are considered to be mechanically weak, incompressible, less dense, and fluid-like [162]. These characteristics make salt layers inherently unstable and are usually deformed by differential sediment loading and gravity spread [30-32]. The salt diapir generally induces many extensional faults that the gas and fluid can migrate through (Figure 6B) [36]. In the Ionian Basin, salt-tectonic structures play a critical role in creating migration pathways (both lateral and vertical) and remobilizing overpressured fluids [163]. The low sediment porosity and permeability in the Ionian zone imply fluid migration through "fracture macro-permeability conduits" in the vicinity of faulted and highly deformed zones [44,45,163].

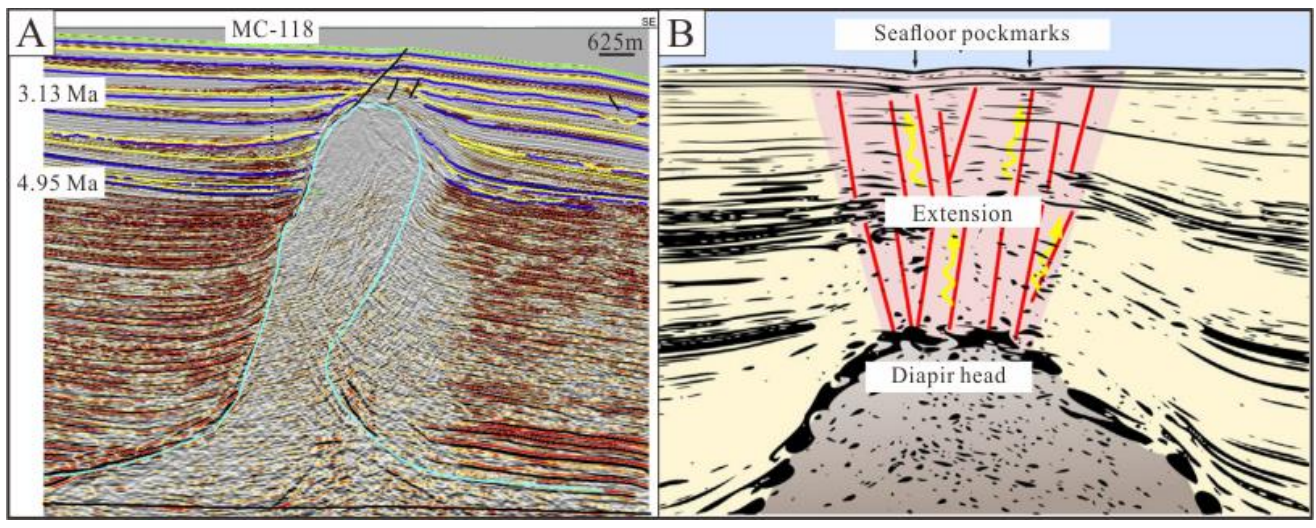

Figure 6. The (A) seismic characteristics (modified from Salazar et al. [164]) and (B) schematic sketch (modified from de Mahiques et al. [36]) of salt diapir.

Critical slope angle is a significant factor that triggers salt tectonic activity $[165,166]$. In an oblique slope, salt layers are supposed to occur as a brittle-ductile layer which generally leads to differential loading, which is thought to initiate the diapir reactivation $[32,167]$. Salt layers generally exist as detachment layers. The overlying sediments can slide along the salt layers under the influence of gravity and then form salt diapirs $[168,169]$. Intense transform-fault activity can also lead to salt diapirs [170]. In that case, the basement faults and the basement steps are thought to control the salt evolution [171-173]. In addition, episodic sedimentation in the depocenter is considered to change local pressure gradients that generally lead to salt diapir [174].

Gravity spread and gravity glide can induce salt diapirs [165]. In the Angolan margin, related salt diapirs are thought to be caused by compressional deformation of the gravity spreading system [175-177]. The salt diapirs in the northern Gulf of Mexico are dominated by gravity gliding [178].

The activities of the salt diapirs induce potential pathways for gas and fluid. Many pockmarks are found located above the faults in the eastern Mediterranean. The faults 
caused by salt diapirs possibly provide conduits for gas and fluid migration [179]. During the salt diapir extrusion, radial faults develop around the top of the diapir and dramatically modify the geometry of the polygonal faults [180]. When the fluid migrates through the salt layers, the salt is transported to the seafloor and then forms a brine pool $[69,70,159]$.

\section{Sediment Ruptures}

Landslides, polygonal faults and tectonic faults are driven by gravity, compaction forces and tectonic forces. The structures have one or multiple prominent rupture surfaces that can provide a conduit for gas and fluid migration.

\subsection{Landslides}

Submarine landslides generally develop in shallow marine sediments on the continental slope, caused by sediments sliding along continental slopes under gravity, with sediments transported from the slope to the deep seafloor (Figure 7A) [181]. The largest documented submarine slide is the Storegga Slide in Norway [182]. The landslide is composed of head-scarp, sliding surface (basal shear surface/basal glide surface), slide-body, and toe-scarp (Figure 7B) [3]. Landslides are considered as mass-transport depositions, and the scales generally range from centimeters to hundreds of kilometers [183,184]. Submarine landslides are soft-sediment deformations with apparent slide surfaces and offsets, which develop in sediment layers with high sedimentation rates, low permeability, and low shear strength [185,186]. Landslide research can estimate the hazards and risks [187], including seabed infrastructure destruction, coastal area collapse, and destructive tsunamis [188-190]. The landslide deposits can help deduce paleo-geological conditions and tectonic activities. Stacked submarine landslide deposits seen in the northern South China Sea are probably induced by multi-period sliding and erosion [191,192]. The canyons are eroded by turbidity currents induced by a landslide, the turbidites deposit in the canyons [193], which reveal the northeastward bottom current. The multi-period landslide deposits are also recognized in the southern Scotia Sea, which are considered as evidence of paleo-earthquakes [194].

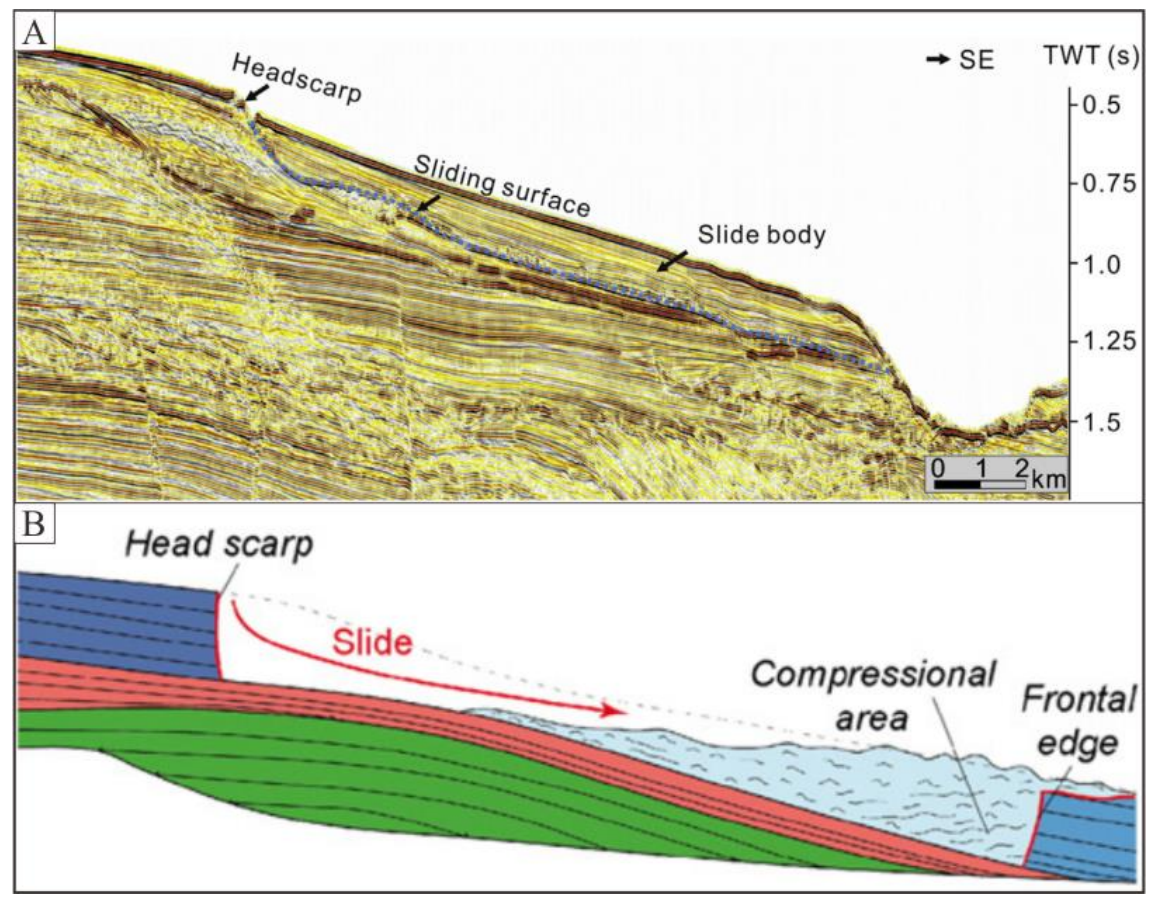

Figure 7. The (A) seismic characteristics (modified from Chen et al. [3]) and (B) descriptive mechanism (modified from Tournadour et al. [195]) of landslide.

Most submarine slopes are inherently stable, and usually require external factors to trigger landslides $[188,196]$. Climate-induced stress variation, including glaciation 
succession, eustatic sea level, rapid sediment load, bottom flow temperature variation, and gas hydrate disassociation, significantly changes the slope stability $[197,198]$. The Storegga Slide located off the Norwegian margin is the largest submarine landslide in the world [158]. The landslide is thought to respond to climatic variability. The Storegga Slide is also a result of rapid loading with excess pore pressure, reducing the effective shear strength of the underlying clays $[188,199]$. Field measurements show that extra pore pressure still exists in the adjacent areas [200].

Salt layers are mechanically weak and flow like fluids [162], which leads to residual friction decreases. As a result, submarine landslides are readily initiated above salt layers. Submarine landslides are observed on the continental slope in the southeastern Mediterranean, whereb they are supposed to interact with a group of step-faults induced by extensional salt tectonic activity [201].

Submarine landslides are probably related to earthquakes and high fluid pressure [183, 196,202], and excess pore pressure is considered the primary pre-condition, and earthquakes trigger the landslides $[190,203]$. High fluid pressure is generally caused by rapid sedimentation and gas and fluid migration. During lower sea level periods, the shallow gas exsolution induces buoyancy increases, leading to pore pressure increases and slope instability [193,204]. In addition, the fluid accumulation leads to sediment liquidation and pore pressure increases. As a result, shallow sediments flow more easily and form shear failures $[26,205]$.

Submarine landslides are generally caused by slope instability, and many factors collectively make significant contributions to slope instability $[189,206]$. As presented above, the pre-condition including soft plastic layers (clay or salt), excess pore pressure, gas-rich sediments, and liquified sediments. The main trigger factors are considered to be earthquakes and storm waves. Submarine slope failures mostly occur on very gentle slopes with gradients of less than $5^{\circ}$ [205], indicating that slope gradients are probably not the dominant factor of the landslide.

Numerous submarine landslides are close to pockmarks and mud volcanoes linked by fluid accumulation [197]. Pockmarks are recognized on the seafloor induced by fluid escape that is probably derived from the underlying mass transport deposits [195]. In addition, pockmark fields are developed adjacent to landslide areas, indicating a close relationship between them in the US continental slope [207] and western Mediterranean Sea [26].

\subsection{Polygonal Faults}

Polygonal faults are generally distributed in passive continental margins [208-211], which develop in fine-grained marine sediments less than 1500 mbsf [37,208,210-223]. Polygonal faults are layer-bound extensional normal faults with an offset of less than $100 \mathrm{~m}$. The fault planes arrange in polygonal patterns in map view (Figure $8 \mathrm{~A}$ ) and as extended layer-bound faults in vertical view (Figure 8B) [208,213-221,223-228].

Polygonal faults are recognized on 2D seismic profiles as block faults [229], extensional faults [230], and layer-bound faults [214]. Polygonal cell-bound faults were first recognized as polygonal patterns on 3D seismic profiles in the North Sea. The faults cut strata into many irregular blocks (Figure 8C) [215]. In recent years, polygonal faults are widely studied in the North Sea [180,213-217,225,227,231-233], the Eromanga Basin [234-236], the South China Sea [237-242], and the Lower Congo Basin [65,133,243].

According to a comprehensive literature investigation, we summarize three formation mechanisms of polygonal faults [244].

Density inversion is a significant mechanism $[211,215,216,229,236]$. Rapid sedimentation generally forms fluid-rich clays. The pore fluid in the upper clay migrates into overlying coarse-grained layers. The pore fluid in the lower clay migrates into underlying coarse-grained layers sealing the pore fluid in the middle clay layer. As compaction continues, the middle pore fluid is difficult to extrude, so that the middle clay density becomes lower than that of the upper clay. This state is termed density inversion and generally leads to gravity instability and shear strength decreases. When the pore fluid pressure exceeds 
the limit, fractures form, and the pore fluid is released. The density inversion indicator is probably the wave-like lithological interfaces induced by differential overpressure and buoyancy accumulation.
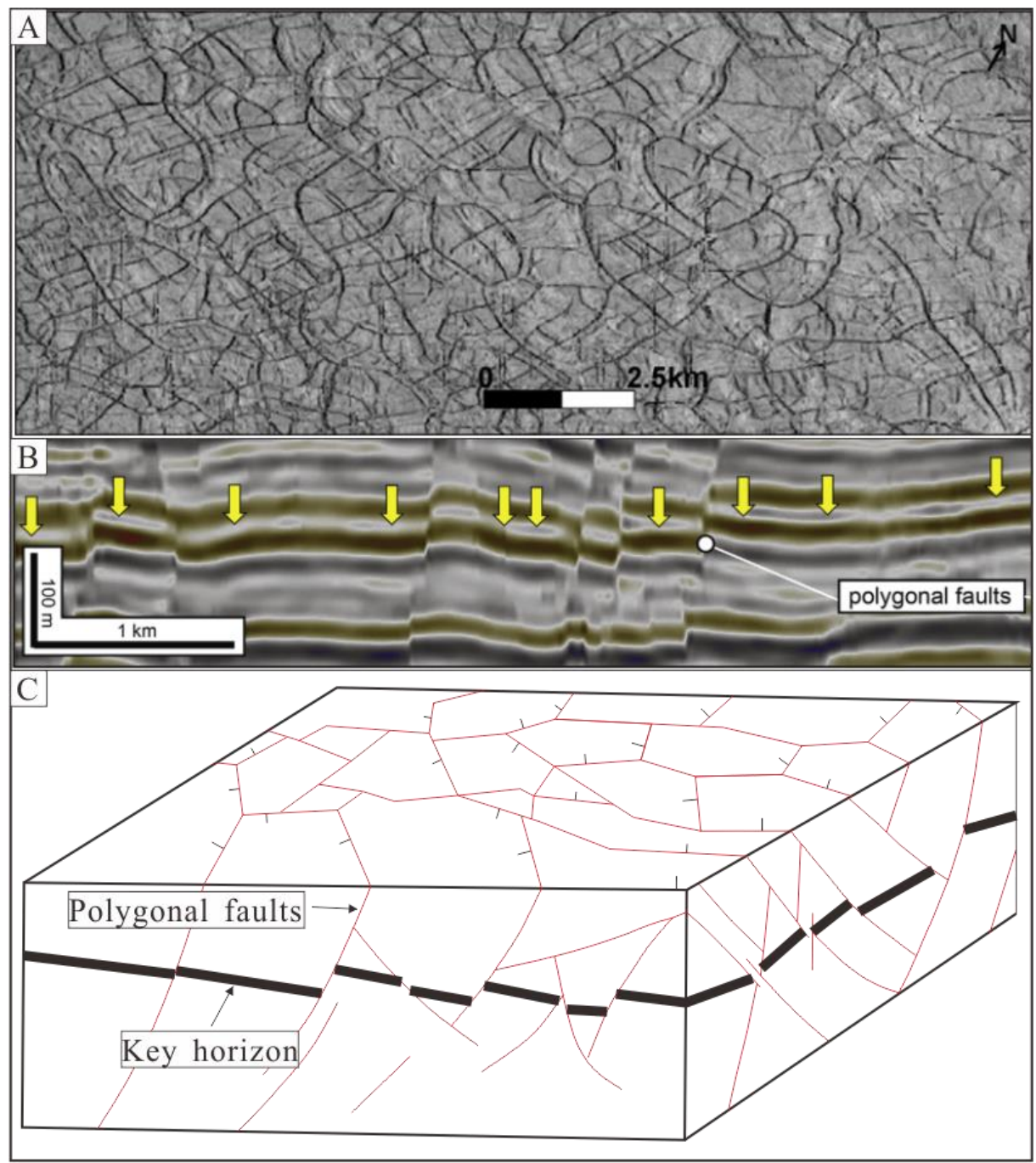

Figure 8. The (A,B) seismic characteristics (modified from Sun et al. [239] and Turrini et al. [37]) and (C) schematic sketch (modified from Cartwright [215]) of polygonal fault.

Syneresis fracture is another mechanism [218,226,232,245-248]. During the early burial, the shallow marine sediments exist in a colloidal state. The fine-grained particles tend to arrange closer to each other under the influence of interparticle attractive forces. As a result, the pore fluid is extruded, and the sediments become more consolidated. The process is suggested to begin at the interface between the seawater and seafloor [243]. As the burial depth increases, the vertical sediments shrink showing normal compaction, and the lateral shrinkage apprears as fractures. The syneresis happens randomly and induces irregular trends and strikes of the polygonal faults.

Shear failure is another mechanism $[208,210,214,217,220,226,246,249,250]$. Researchers proposed to use the Mohr-Coulomb Law to explain the formation of polygonal faults. The shear strength of water-saturated sediments is weaker than that of rock; therefore, these sediments more comfortably form shear failures. In the Mohr Circle, shear failure forms when the Mohr Circle contacts the Mohr-Coulomb Failure Envelopes. Two factors make contributions to the location and size of the Mohr Circle. First, lateral extensional stress induced by compaction increases as the burial depth increases, inducing a minimum principal stress decrease and the radius of Mohr Circle increases. When the Mohr Circle 
contacts the Mohr-Coulomb Failure Envelopes, shear failures form. Second, continuous pore pressure increases lead to a decrease of the maximum principal stress and the minimum principal stress. The Mohr Circle shifts leftward and contacts the Mohr-Coulomb Failure Envelopes, and shear failures form. In addition, the coefficient of friction in finegrained sediments is thought to be exceptionally low, and fractures more easily form under the mechanical compaction induced by gravity $[210,220,251]$.

Fine-grained sediments are considered as the sealing layers in the marine environment $[223,246]$, but the occurrence of polygonal faults substantially improves the permeability of fine-grained layers [252]. Therefore, polygonal faults are the relief pathway of pore fluid pressure and the migration pathway of the deep hydrocarbon gases and fluids $[212,222,239,253,254]$. For one thing, polygonal faults improve the permeability of the fine-grained layers and have a negative influence on the burial of $\mathrm{CO}_{2}$ and nuclear waste under seafloor $[223,246,249]$. For another thing, the permeability increase positively influences the upward migration of hydrocarbon gas and fluid that migrate through the polygonal faults to the GHSZ and form gas hydrates [208].

Pockmarks and gas pipes are recognized off the shore of Norway. Most of them are distributed above polygonal faults, indicating that the gas and fluid migrated through the polygonal faults and was released at the pockmarks [255]. Some polygonal faults extend to the seafloor with pockmarks above them, and some gas pipes are distributed at the top end of the polygonal faults $[107,123,243]$.

\subsection{Tectonic Faults}

Tectonic faults are generally developed around the plate boundaries in both continents and oceans. An active submarine fault is one of the tectonic faults used to describe repeat fault activities in recent geological time, indicating periodic tectonic activities such as earthquakes $[28,38,256-260]$. Tectonic faults are generally recognized by reflector deformation, offset, and divarication (Figure 9A). Submarine active faults connect the deep underlying strata with the seafloor, providing effective pathways for deep thermogenic gases and fluids [28]. Therefore, the faults can help to estimate the hydrocarbon gas and fluid sources. Submarine active faults are mainly studied in the Sea of Marmara (Figure 9B) $[28,38,256,258,261-268]$, the eastern Mediterranean Sea [269,270], the Aegean Sea [271] and the Japan Sea [272-274].

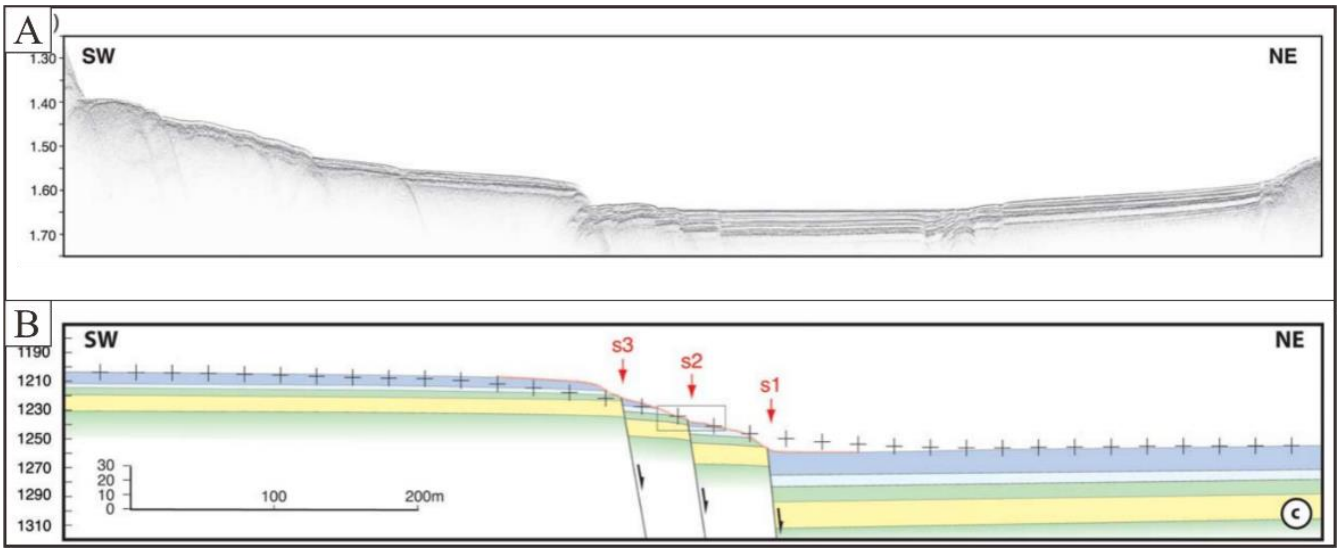

Figure 9. The (A) seismic characteristics (modified from Géli et al. [264]) and (B) descriptive sketch (modified from Géli et al. [264]) of tectonic fault.

The North-Anatolian Fault (NAF) is taken as an example. The NAF is a continental transform fault distributed along the boundary of the Anatolian plate and Eurasian plate, which is thought to induce devastating earthquakes. The fault splays into three branches, and two branches make up the boundary of the Sea of Marmara [28]. The NAF is induced by Anatolia-Aegean block westward escape because of the Arabia plate subduction into the Eurasia Plate [256]. As a result, deep thermogenic hydrocarbon gases and fluids 
migrate upward along the fault planes and form cold seepages on the seafloor [263]. Authigenic carbonate and microbial mats are also observed on the seafloor along the fault segment $[28,263]$. The faults are characterized by creep deformation and abrupt deformation, and any abrupt deformation is generally produced by earthquakes. Previous studies indicated that most earthquakes are reactive along the initial active faults [257-259].

Acoustic anomalies indicating the gas venting are recognized on acoustic profiles. The anomalies are distributed along NAF in the Sea of Marmara, revealing a close relationship between gas seepage and fault activities [264]. Active seepage is observed above the NAF, which is considered as a conduit for the gas seepage [28].

\section{Summary and Perspectives}

Shallow marine structures are developed in shallow sediments at depths of less than $1000 \mathrm{mbsf}$. According to their characteristics and formation mechanisms, these structures are classified into three groups: overpressure-associated structures, diapir structures and sediment ruptures.

The overpressure-associated structures are mainly induced by pore pressure changes related to gas and fluid accumulation, migration and release, including seepages, pockmarks and gas chimneys. Diapir structures are primarily driven by differential loading and gravity spread in plastic layers and include mud diapirs and salt diapirs. The sediment ruptures are associated with gravity, compaction forces and tectonic forces, and including landslides, polygonal faults and tectonic faults. In general, each structure would not be induced by a single mechanism, and many external factors might have been involved.

These structures can be paths for gas and fluid migration. The tectonic faults (Figure 10H) generally cut into deep hydrocarbon reservoirs and extend laterally a long distance, being the primary pathways for deep thermogenic gases. Some tectonic faults vertically extend into shallow horizons and act as shallow gas pathways. The polygonal faults (Figure 10G) are generally formed in deep and shallow fine-grained sediment layers that enhance the sediment permeability. The deep polygonal faults are suggested to play a role as pathways for the gas and fluid migration and the shallow ones form as reservoirs. Abundant gas and fluid accumulation in fine-grained sediments can decrease the sediment density and shear strength, making the layers easy to deform and offset by differential forces. As a result, the deeply buried layers form mud diapirs (Figure 10D), and the shallow layers form landslides (Figure 10F). The mud diapirs with high gas and fluid saturation erupt at the seafloor and form mud volcanoes (Figure 10D), releasing gases and fluids into the seawater. When the mud diapirs extrude through a salt diapir (Figure 10E) area, the salt dissolves and is carried to the seafloor to form a brine pool. However, the mud diapirs with low gas and fluid saturation extrude to the seafloor and form mud mounds (Figure 10D). When the gas and fluid accumulate in shallow layers and form an overpressure, pre-existing or after-born gas chimneys are the preferential migration pathways. Some gas chimneys (Figure 10C) extend vertically into the seafloor to release the overpressured gases and fluids. A strong overpressure can form a vigorous seepage (Figure 10A), and a weak overpressure forms a gentle seepage. The sediments around the seepage site are disturbed by the gas and fluid flow, leaving a pockmark (Figure 10B) on the seafloor. A regular and continuous flow can form a circular pockmark, and the irregular and episodic ones form irregular pockmarks.

These shallow structures have significant impacts on the gas hydrate and authigenic carbonate distribution. Gas hydrates are formed at relatively low temperatures and high pressures by hydrocarbon gases and water that is widely found in shallow marine sediments. The gas source is generally composed of deep thermogenic gases and shallow biogenic gases. The gases migrate upward along the pathways provided by the structures to the GHSZ and sulfate-methane interface (SMI) and form gas hydrates and authigenic carbonates, respectively. However, gas hydrates and authigenic carbonates are tight layers that generally seal the pathway and induce overpressures beneath them. With the increase in overpressure, a new pathway breaks through or bypasses the sealing area driven by pressure. The new pathway is generally a new gas chimney that extends to the seafloor and 
forms a seepage. In some cases, the sealing layers are developed at a very shallow depth, and the gas hydrates and authigenic carbonates are blown out to the seafloor and deposit around the seepage site. Some bacterial species can feed on methane and take part in the methane and sulfate geochemical cycle, so sometimes gas hydrates, authigenic carbonates and bacterial communities occur associatively around a seepage site.

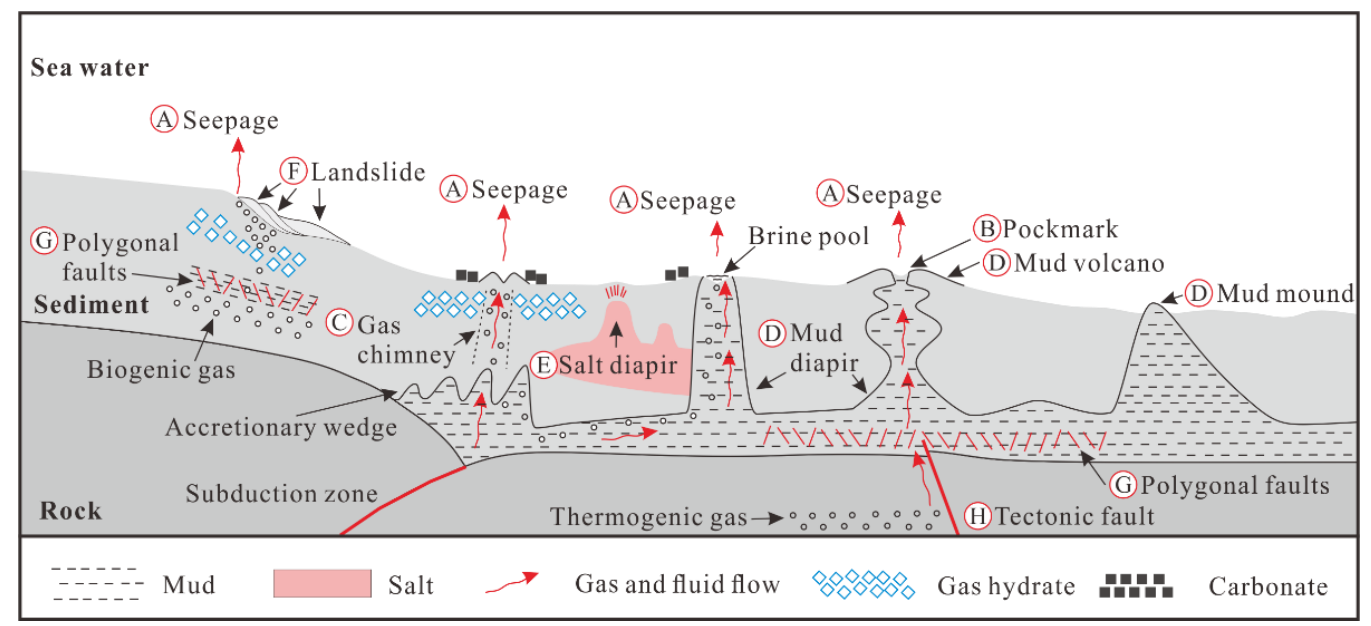

Figure 10. A comprehensive schematic description of the shallow structures developed in marine sediments.

Author Contributions: H.L. and G.H. conceptualized the study; G.M. wrote the original draft; L.Z. contributed to refining the draft and all authors contributed to editing and final reviews of the paper. All authors have read and agreed to the published version of the manuscript.

Funding: This research received no external funding.

Institutional Review Board Statement: Not applicable.

Informed Consent Statement: Not applicable.

Data Availability Statement: Not applicable.

Acknowledgments: The authors gratefully acknowledge the financial supports from the Ministry of Science and Technology of China (2017YFC0307603) and from the China Geological Survey (DD20190234). We also thank all the colleagues in Beijing International Center for Gas Hydrate for their comments and suggestions.

Conflicts of Interest: The authors declare no conflict of interest.

\section{References}

1. Berton, F.; Vesely, F.F. Origin of buried, bottom current-related comet marks and associated submarine bedforms from a Paleogene continental margin, southeastern Brazil. Mar. Geol. 2018, 395, 347-362. [CrossRef]

2. Shakhova, N.; Semiletov, I.; Gustafsson, O.; Sergienko, V.; Lobkovsky, L.; Dudarev, O.; Tumskoy, V.; Grigoriev, M.; Mazurov, A.; Salyuk, A.; et al. Current rates and mechanisms of subsea permafrost degradation in the East Siberian Arctic Shelf. Nat. Commun. 2017, 8, 15872. [CrossRef]

3. Chen, D.; Wang, X.; Völker, D.; Wu, S.; Wang, L.; Li, W.; Li, Q.; Zhu, Z.; Li, C.; Qin, Z. Three dimensional seismic studies of deep-water hazard-related features on the northern slope of South China Sea. Mar. Pet. Geol. 2016, 77, 1125-1139. [CrossRef]

4. Matsumoto, R.; Hiromatsu, M.; Sato, M. Fluid flow and Evolution of gas hydrate mounds of Joetsu Basin, Eastern Margin of Japan Sea: Constraints from high-resolution geophysical survey by AUV. In Proceedings of the 7th International Conference on Gas Hydrate, Edinburgh, UK, 17-21 July 2011.

5. Chen, S.-C.; Hsu, S.-K.; Wang, Y.; Chung, S.-H.; Chen, P.-C.; Tsai, C.-H.; Liu, C.-S.; Lin, H.-S.; Lee, Y.-W. Distribution and characters of the mud diapirs and mud volcanoes off southwest Taiwan. J. Asian Earth Sci. 2014, 92, 201-214. [CrossRef]

6. Ho, S.; Dan, C.; Imbert, P. Insights into the permeability of polygonal faults from their intersection geometries with Linear Chimneys: A case study from the Lower Congo Basin. Carnets Geol. 2016, 16, 17-26. [CrossRef]

7. Li, J.; Ye, J.; Qin, X.; Qiu, H.; Wu, N.; Lu, H.; Xie, W.; Lu, J.; Peng, F.; Xu, Z.; et al. The first offshore natural gas hydrate production test in South China Sea. China Geol. 2018, 1, 5-16. [CrossRef] 
8. Sloan, E.D. Fundamental principles and applications of natural gas hydrates. Nature 2003, 426, 353. [CrossRef]

9. Lu, H.; Seo, Y.-T.; Lee, J.-W.; Moudrakovski, I.; Ripmeester, J.A.; Chapman, N.R.; Coffin, R.B.; Gardner, G.; Pohlman, J. Complex gas hydrate from the Cascadia margin. Nature 2007, 445, 303. [CrossRef] [PubMed]

10. Wei, J.; Fang, Y.; Lu, H.; Lu, H.; Lu, J.; Liang, J.; Yang, S. Distribution and characteristics of natural gas hydrates in the Shenhu Sea Area, South China Sea. Mar. Pet. Geol. 2018, 98, 622-628. [CrossRef]

11. Wei, J.; Liang, J.; Lu, J.; Zhang, W.; He, Y. Characteristics and dynamics of gas hydrate systems in the northwestern South China Sea-Results of the fifth gas hydrate drilling expedition. Mar. Pet. Geol. 2019, 110, 287-298. [CrossRef]

12. Ye, J.; Wei, J.; Liang, J.; Lu, J.; Lu, H.; Zhang, W. Complex gas hydrate system in a gas chimney, South China Sea. Mar. Pet. Geol. 2019, 104, 29-39. [CrossRef]

13. Berndt, C.; Feseker, T.; Treude, T.; Krastel, S.; Liebetrau, V.; Niemann, H.; Bertics, V.J.; Dumke, I.; Dünnbier, K.; Ferré, B. Temporal constraints on hydrate-controlled methane seepage off Svalbard. Science 2014, 343, 284-287. [CrossRef] [PubMed]

14. Biastoch, A.; Treude, T.; Rüpke, L.H.; Riebesell, U.; Roth, C.; Burwicz, E.B.; Park, W.; Latif, M.; Böning, C.W.; Madec, G. Rising Arctic Ocean temperatures cause gas hydrate destabilization and ocean acidification. Geophys. Res. Lett. 2011, 38. [CrossRef]

15. Boudreau, B.P.; Luo, Y.; Meysman, F.J.; Middelburg, J.J.; Dickens, G.R. Gas hydrate dissociation prolongs acidification of the Anthropocene oceans. Geophys. Res. Lett. 2015, 42, 9337-9344A. [CrossRef]

16. Skarke, A.; Ruppel, C.; Kodis, M.; Brothers, D.; Lobecker, E. Widespread methane leakage from the sea floor on the northern US Atlantic margin. Nat. Geosci. 2014, 7, 657-661. [CrossRef]

17. Han, W.-C.; Chen, L.; Liu, C.-S.; Berndt, C.; Chi, W.-C. Seismic analysis of the gas hydrate system at Pointer Ridge offshore SW Taiwan. Mar. Pet. Geol. 2019, 105, 158-167. [CrossRef]

18. Zhang, W.; Liang, J.; Su, P.; Wei, J.; Gong, Y.; Lin, L.; Liang, J.; Huang, W. Distribution and characteristics of mud diapirs, gas chimneys, and bottom simulating reflectors associated with hydrocarbon migration and gas hydrate accumulation in the Qiongdongnan Basin, northern slope of the South China Sea. Geol. J. 2019, 54, 3556-3573. [CrossRef]

19. Li, A.; Davies, R.J.; Mathias, S.A.; Yang, J.; Hobbs, R.; Wilson, M. Gas venting that bypasses the feather edge of marine hydrate, offshore Mauritania. Mar. Pet. Geol. 2017, 88, 402-409. [CrossRef]

20. Wenau, S.; Spieß, V.; Pape, T.; Fekete, N. Controlling mechanisms of giant deep water pockmarks in the Lower Congo Basin. Mar. Pet. Geol. 2017, 83, 140-157. [CrossRef]

21. Bei, K.; Xu, T.; Shang, S.; Wei, Z.; Yuan, Y.; Tian, H. Numerical Modeling of Gas Migration and Hydrate Formation in Heterogeneous Marine Sediments. J. Mar. Sci. Eng. 2019, 7, 348. [CrossRef]

22. Wang, X.; Liu, B.; Qian, J.; Zhang, X.; Guo, Y.; Su, P.; Liang, J.; Jin, J.; Luan, Z.; Chen, D. Geophysical evidence for gas hydrate accumulation related to methane seepage in the Taixinan Basin, South China Sea. J. Asian Earth Sci. 2018, 168, 27-37. [CrossRef]

23. Lu, Y.; Luan, X.; Lyu, F.; Wang, B.; Yang, Z.; Yang, T.; Yao, G. Seismic evidence and formation mechanism of gas hydrates in the Zhongjiannan Basin, Western margin of the South China Sea. Mar. Pet. Geol. 2017, 84, 274-288. [CrossRef]

24. Martínez-Carreño, N.; García-Gil, S. The Holocene gas system of the Ría de Vigo (NW Spain): Factors controlling the location of gas accumulations, seeps and pockmarks. Mar. Geol. 2013, 344, 82-100. [CrossRef]

25. Taylor, M.H.; Dillon, W.P.; Pecher, I.A. Trapping and migration of methane associated with the gas hydrate stability zone at the Blake Ridge Diapir: New insights from seismic data. Mar. Geol. 2000, 164, 79-89. [CrossRef]

26. Lastras, G.; Canals, M.; Urgeles, R.; Hughes-Clarke, J.E.; Acosta, J. Shallow slides and pockmark swarms in the Eivissa Channel, western Mediterranean Sea. Sedimentology 2004, 51, 837-850. [CrossRef]

27. Alrefaee, H.A.; Gosh, S.; Abdel-Fattah, M.I. 3D seismic characterization of the polygonal fault systems and its impact on fluid flow migration: An example from the Northern Carnarvon Basin, Australia. J. Pet. Sci. Eng. 2018, 167. [CrossRef]

28. Gasperini, L.; Polonia, A.; Bianco, F.D.; Favali, P.; Marinaro, G.; Etiope, G. Cold seeps, active faults and the earthquake cycle along the North Anatolian Fault system in the Sea of Marmara (NE Turkey). Boll. di Geofis. Teor. ed Appl. 2012, 53, 371-384.

29. Gamberi, F.; Rovere, M. Mud diapirs, mud volcanoes and fluid flow in the rear of the Calabrian Arc Orogenic Wedge (southeastern Tyrrhenian sea). Basin Res. 2010, 22, 452-464. [CrossRef]

30. Albertz, M.; Beaumont, C.; Shimeld, J.W.; Ings, S.J.; Gradmann, S. An investigation of salt tectonic structural styles in the Scotian Basin, offshore Atlantic Canada: 1. Comparison of observations with geometrically simple numerical models. Tectonics 2010, 29, TC4017. [CrossRef]

31. Vendeville, B.C. Salt tectonics driven by sediment progradation: Part I-Mechanics and kinematics. AAPG Bull. 2005, 89, 1071-1079. [CrossRef]

32. Al-Zoubi, A.; Uri, S. Salt diapirs in the Dead Sea basin and their relationship to Quaternary extensional tectonics. Mar. Pet. Geol. 2001, 18, 779-797. [CrossRef]

33. Goswami, B.K.; Weitemeyer, K.A.; Bünz, S.; Minshull, T.A.; Westbrook, G.K.; Ker, S.; Sinha, M.C. Variations in pockmark composition at the Vestnesa Ridge: Insights from marine controlled source electromagnetic and seismic data. Geochem. Geophys. Geosystems 2017, 18, 1111-1125. [CrossRef]

34. Wood, W.T.; Gettrust, J.F.; Chapman, N.R.; Spence, G.D.; Hyndman, R.D. Decreased stability of methane hydrates in marine sediments owing to phase-boundary roughness. Nature 2002, 420,656. [CrossRef]

35. Hsu, H.-H.; Liu, C.-S.; Chang, Y.-T.; Chang, J.-H.; Ko, C.-C.; Chiu, S.-D.; Chen, S.-C. Diapiric activities and intraslope basin development offshore of SW Taiwan: A case study of the Lower Fangliao Basin gas hydrate prospect. J. Asian Earth Sci. 2017, 149, 145-159. [CrossRef] 
36. de Mahiques, M.M.; Schattner, U.; Lazar, M.; Sumida, P.Y.; Souza, L.A. An extensive pockmark field on the upper Atlantic margin of Southeast Brazil: Spatial analysis and its relationship with salt diapirism. Heliyon 2017, 3, e00257. [CrossRef]

37. Turrini, L.; Jackson, C.A.L.; Thompson, P. Seal rock deformation by polygonal faulting, offshore Uruguay. Mar. Pet. Geol. 2017, 86, 892-907. [CrossRef]

38. Armijo, R.; Pondard, N.; Meyer, B.; Uçarkus, G.; Lépinay, B.M.D.; Malavieille, J.; Dominguez, S.; Gustcher, M.A.; Schmidt, S.; Beck, C. Submarine fault scarps in the Sea of Marmara pull-apart (North Anatolian Fault): Implications for seismic hazard in Istanbul. Geochem. Geophys. Geosystems 2013, 6, 453-468. [CrossRef]

39. Yu, Z.; Lerche, I. Modelling abnormal pressure development in sandstone/shale basins. Mar. Pet. Geol. 1996, 13, 179-193. [CrossRef]

40. Bertoni, C.; Cartwright, J. Messinian evaporites and fluid flow. Mar. Pet. Geol. 2015, 66, 165-176. [CrossRef]

41. Al-Balushi, A.N.; Neumaier, M.; Fraser, A.J.; Jackson, C.A. The impact of the Messinian salinity crisis on the petroleum system of the Eastern Mediterranean: A critical assessment using 2D petroleum system modelling. Pet. Geosci. 2016, 22, 357-379. [CrossRef]

42. Bertoni, C.; Kirkham, C.; Cartwright, J.; Hodgson, N.; Rodriguez, K. Seismic indicators of focused fluid flow and cross-evaporitic seepage in the Eastern Mediterranean. Mar. Pet. Geol. 2017, 88, 472-488. [CrossRef]

43. Kirkham, C.; Cartwright, J.; Hermanrud, C.; Jebsen, C. The genesis of mud volcano conduits through thick evaporite sequences. Basin Res. 2018, 30, 217-236. [CrossRef]

44. Kontakiotis, G.; Karakitsios, V.; Maravelis, A.G.; Zarkogiannis, S.D.; Agiadi, K.; Antonarakou, A.; Pasadakis, N.; Zelilidis, A Integrated isotopic and organic geochemical constraints on the depositional controls and source rock quality of the Neogene Kalamaki sedimentary successions (Zakynthos Island, Ionian Sea). Mediterr. Geosci. Rev. 2020. [CrossRef]

45. Kontakiotis, G.; Moforis, L.; Karakitsios, V.; Antonarakou, A. Sedimentary Facies Analysis, Reservoir Characteristics and Paleogeography Significance of the Early Jurassic to Eocene Carbonates in Epirus (Ionian Zone, Western Greece). J. Mar. Sci. Eng. 2020, 8, 706. [CrossRef]

46. Kontakiotis, G.; Karakitsios, V.; Cornée, J.-J.; Moissette, P.; Zarkogiannis, S.D.; Pasadakis, N.; Koskeridou, E.; Manoutsoglou, E.; Drinia, H.; Antonarakou, A. Preliminary results based on geochemical sedimentary constraints on the hydrocarbon potential and depositional environment of a Messinian sub-salt mixed siliciclastic-carbonate succession onshore Crete (Plouti section, eastern Mediterranean). Mediterr. Geosci. Rev. 2020, 2, 247-265. [CrossRef]

47. Talukder, A.R. Review of submarine cold seep plumbing systems: Leakage to seepage and venting. Terra Nova 2012, 24, 255-272. [CrossRef]

48. Feng, D.; Chen, D. Authigenic carbonates from an active cold seep of the northern South China Sea: New insights into fluid sources and past seepage activity. Deep Sea Res. Part II Top. Stud. Oceanogr. 2015, 122, 74-83. [CrossRef]

49. Feng, D.; Birgel, D.; Peckmann, J.; Roberts, H.H.; Joye, S.B.; Sassen, R.; Liu, X.-L.; Hinrichs, K.-U.; Chen, D. Time integrated variation of sources of fluids and seepage dynamics archived in authigenic carbonates from Gulf of Mexico Gas Hydrate Seafloor Observatory. Chem. Geol. 2014, 385, 129-139. [CrossRef]

50. Crutchley, G.J.; Klaeschen, D.; Planert, L.; Bialas, J.; Berndt, C.; Papenberg, C.; Hensen, C.; Hornbach, M.J.; Krastel, S.; Brueckmann, W. The impact of fluid advection on gas hydrate stability: Investigations at sites of methane seepage offshore Costa Rica. Earth Planet. Sci. Lett. 2014, 401, 95-109. [CrossRef]

51. Crutchley, G.J.; Berndt, C.; Geiger, S.; Klaeschen, D.; Papenberg, C.; Klaucke, I.; Hornbach, M.J.; Bangs, N.L.B.; Maier, C. Drivers of focused fluid flow and methane seepage at south Hydrate Ridge, offshore Oregon, USA. Geology 2013, 41, 551-554. [CrossRef]

52. Naeth, J.; Primio, R.D.; Horsfield, B.; Schaefer, R.G.; Shannon, P.M.; Bailey, W.R.; Henriet, J.P. Hydrocarbon seepage and carbonate mound formation: A basin modelling study from the Porcupine Basin (offshore Ireland). J. Pet. Geol. 2010, 28, 147-166. [CrossRef]

53. Klaucke, I.; Weinrebe, W.; Petersen, C.J.; Bowden, D. Temporal variability of gas seeps offshore New Zealand: Multi-frequency geoacoustic imaging of the Wairarapa area, Hikurangi margin. Mar. Geol. 2010, 272, 49-58. [CrossRef]

54. Klaucke, I.; Sahling, H.; Weinrebe, W.; Blinova, V.; Bürk, D.; Lursmanashvili, N.; Bohrmann, G. Acoustic investigation of cold seeps offshore Georgia, eastern Black Sea. Mar. Geol. 2006, 231, 51-67. [CrossRef]

55. Hustoft, S.; Bünz, S.; Mienert, J.; Chand, S. Gas hydrate reservoir and active methane-venting province in sediments on $<20 \mathrm{Ma}$ young oceanic crust in the Fram Strait, offshore NW-Svalbard. Earth Planet. Sci. Lett. 2009, 284, 12-24. [CrossRef]

56. Fang, Y.; Wei, J.; Lu, H.; Liang, J.; Lu, J.A.; Fu, J.; Cao, J. Chemical and Structural Characteristics of Gas Hydrates from the Haima Cold Seeps in the Qiongdongnan Basin of the South China Sea. J. Asian Earth Sci. 2019, 103924. [CrossRef]

57. Hovland, M. On the self-sealing nature of marine seeps. Cont. Shelf Res. 2002, 22, 2387-2394. [CrossRef]

58. Tryon, M.D.; Brown, K.M.; Torres, M.E. Fluid and chemical flux in and out of sediments hosting methane hydrate deposits on Hydrate Ridge, OR, II: Hydrological processes. Earth Planet. Sci. Lett. 2002, 201, 541-557. [CrossRef]

59. Hasiotis, T.; Papatheodorou, G.; Ferentinos, G. A string of large and deep gas-induced depressions (pockmarks) offshore Killini peninsula, western Greece. Geo-Mar. Lett. 2002, 22, 142-149. [CrossRef]

60. Dando, P.R. Ecology of a North Sea pockmark with an active methane seep. Mar. Ecol. Prog. 1991, 70, 49-63. [CrossRef]

61. Fader, G.B.J. Gas-related sedimentary features from the eastern Canadian continental shelf. Cont. Shelf Res. 1991, 11, 1123-1153. [CrossRef]

62. Mazzini, A.; Svensen, H.H.; Forsberg, C.F.; Linge, H.; Lauritzen, S.-E.; Haflidason, H.; Hammer, Ø.; Planke, S.; Tjelta, T.I. A climatic trigger for the giant Troll pockmark field in the northern North Sea. Earth Planet. Sci. Lett. 2017, 464, 24-34. [CrossRef] 
63. de Prunelé, A.; Ruffine, L.; Riboulot, V.; Peters, C.A.; Croguennec, C.; Guyader, V.; Pape, T.; Bollinger, C.; Bayon, G.; Caprais, J.-C.; et al. Focused hydrocarbon-migration in shallow sediments of a pockmark cluster in the Niger Delta (Off Nigeria). Geochem. Geophys. Geosystems 2017, 18, 93-112. [CrossRef]

64. Chand, S.; Crémière, A.; Lepland, A.; Thorsnes, T.; Brunstad, H.; Stoddart, D. Long-term fluid expulsion revealed by carbonate crusts and pockmarks connected to subsurface gas anomalies and palaeo-channels in the central North Sea. Geo-Mar. Lett. 2016, 37, 215-227. [CrossRef]

65. Gay, A.; Lopez, M.; Cochonat, P.; Séranne, M.; Levaché, D.; Sermondadaz, G. Isolated seafloor pockmarks linked to BSRs, fluid chimneys, polygonal faults and stacked Oligocene-Miocene turbiditic palaeochannels in the Lower Congo Basin. Mar. Geol. 2006, 226, 25-40. [CrossRef]

66. Schroot, B.M.; Klaver, G.T.; Schüttenhelm, R.T.E. Surface and subsurface expressions of gas seepage to the seabed-Examples from the Southern North Sea. Mar. Pet. Geol. 2005, 22, 499-515. [CrossRef]

67. Feldens, P.; Schmidt, M.; Mücke, I.; Augustin, N.; Al-Farawati, R.; Orif, M.; Faber, E. Expelled subsalt fluids form a pockmark field in the eastern Red Sea. Geo-Mar. Lett. 2016, 36, 339-352. [CrossRef]

68. Dimitrov, L.; Woodside, J. Deep sea pockmark environments in the eastern Mediterranean. Mar. Geol. 2003, 195, 263-276. [CrossRef]

69. Woodside, J.M.; Volgin, A.V. Brine pools associated with Mediterranean Ridge mud diapirs: An interpretation of echo-free patches in deep tow sidescan sonar data. Mar. Geol. 1996, 132, 55-61. [CrossRef]

70. Mascle, J.; Mary, F.; Praeg, D.; Brosolo, L.; Camera, L.; Ceramicola, S.; Dupré, S. Distribution and geological control of mud volcanoes and other fluid/free gas seepage features in the Mediterranean Sea and nearby Gulf of Cadiz. Geo-Mar. Lett. 2014, 34, 89-110. [CrossRef]

71. Weinberger, J.L.; Brown, K.M. Fracture networks and hydrate distribution at Hydrate Ridge, Oregon. Earth Planet. Sci. Lett. 2006, 245, 123-136. [CrossRef]

72. Tryon, M.D.; Brown, K.M.; Torres, M.E.; Tréhu, A.M.; McManus, J.; Collier, R.W.J.G. Measurements of transience and downward fluid flow near episodic methane gas vents, Hydrate Ridge, Cascadia. Geology 1999, 27, 1075-1078. [CrossRef]

73. Tréhu, A.M.; Long, P.E.; Torres, M.E.; Bohrmann, G.; Rack, F.R.; Collett, T.S.; Goldberg, D.S.; Milkov, A.V.; Riedel, M.; Schultheiss, P.; et al. Three-dimensional distribution of gas hydrate beneath southern Hydrate Ridge: Constraints from ODP Leg 204. Earth Planet. Sci. Lett. 2004, 222, 845-862. [CrossRef]

74. Linke, P.; Suess, E.; Torres, M.; Martens, V.; Rugh, W.D.; Ziebis, W.; Kulm, L.D. In situ measurement of fluid flow from cold seeps at active continental margins. Deep Sea Res. Part I Oceanogr. Res. Pap. 1994, 41, 721-739. [CrossRef]

75. Nakajima, T.; Kakuwa, Y.; Yasudomi, Y.; Itaki, T.; Motoyama, I.; Tomiyama, T.; Machiyama, H.; Katayama, H.; Okitsu, O.; Morita, S. Formation of pockmarks and submarine canyons associated with dissociation of gas hydrates on the Joetsu Knoll, eastern margin of the Sea of Japan. J. Asian Earth Sci. 2014, 90, 228-242. [CrossRef]

76. Hovland, M.; Judd, A.G.; King, L.H. Characteristic features of pockmarks on the North Sea Floor and Scotian Shelf. Sedimentology 2010, 31, 471-480. [CrossRef]

77. Hovland, M. Do carbonate reefs form due to fluid seepage? Terra Nova 2010, 2, 8-18. [CrossRef]

78. Hovland, M.; Svensen, H.; Forsberg, C.F.; Johansen, H.; Fichler, C.; Fosså, J.H.; Jonsson, R.; Rueslåtten, H. Complex pockmarks with carbonate-ridges off mid-Norway: Products of sediment degassing. Mar. Geol. 2005, 218, 191-206. [CrossRef]

79. Ho, S.; Cartwright, J.A.; Imbert, P. Vertical evolution of fluid venting structures in relation to gas flux, in the Neogene-Quaternary of the Lower Congo Basin, Offshore Angola. Mar. Geol. 2012, 332-334, 40-55. [CrossRef]

80. Macdonald, I.R.; Guinasso, N.L., Jr.; Sassen, R.; Brooks, J.M.; Lee, L.; Scott, K.T. Gas hydrate that breaches the sea floor on the continental slope of the Gulf of Mexico. Geology 1994, 22, 699-702. [CrossRef]

81. Neurauter, T.W.; Roberts, H.H. Three generations of mud volcanoes on the Louisiana continental slope. Geo-Mar. Lett. 1994, 14, 120-125. [CrossRef]

82. Han, X.; Suess, E.; Huang, Y.; Wu, N.; Bohrmann, G.; Su, X.; Eisenhauer, A.; Rehder, G.; Fang, Y. Jiulong methane reef: Microbial mediation of seep carbonates in the South China Sea. Mar. Geol. 2008, 249, 243-256. [CrossRef]

83. Sager, W.W.; Macdonald, I.R.; Hou, R. Geophysical signatures of mud mounds at hydrocarbon seeps on the Louisiana continental slope, northern Gulf of Mexico. Mar. Geol. 2003, 198, 97-132. [CrossRef]

84. Riboulot, V.; Sultan, N.; Imbert, P.; Ker, S. Initiation of gas-hydrate pockmark in deep-water Nigeria: Geo-mechanical analysis and modelling. Earth Planet. Sci. Lett. 2016, 434, 252-263. [CrossRef]

85. Mazzini, A.; Svensen, H.H.; Planke, S.; Forsberg, C.F.; Tjelta, T.I. Pockmarks and methanogenic carbonates above the giant Troll gas field in the Norwegian North Sea. Mar. Geol. 2016, 373, 26-38. [CrossRef]

86. Hong, W.L.; Sauer, S.; Panieri, G.; Ambrose, W.G.; James, R.H.; Plaza-Faverola, A.; Schneider, A. Removal of methane through hydrological, microbial, and geochemical processes in the shallow sediments of pockmarks along eastern Vestnesa Ridge (Svalbard). Limnol. Oceanogr. 2016, 61. [CrossRef]

87. Nöthen, K.; Kasten, S. Reconstructing changes in seep activity by means of pore water and solid phase $\mathrm{Sr} / \mathrm{Ca}$ and $\mathrm{Mg} / \mathrm{Ca}$ ratios in pockmark sediments of the Northern Congo Fan. Mar. Geol. 2011, 287, 1-13. [CrossRef]

88. Feng, D.; Chen, D.; Peckmann, J.; Bohrmann, G. Authigenic carbonates from methane seeps of the northern Congo fan: Microbial formation mechanism. Mar. Pet. Geol. 2010, 27, 748-756. [CrossRef] 
89. Han, X.; Suess, E.; Liebetrau, V.; Eisenhauer, A.; Huang, Y. Past methane release events and environmental conditions at the upper continental slope of the South China Sea: Constraints by seep carbonates. Int. J. Earth Sci. 2014, 103, 1873-1887. [CrossRef]

90. Panieri, G.; Bünz, S.; Fornari, D.J.; Escartin, J.; Serov, P.; Jansson, P.; Torres, M.E.; Johnson, J.E.; Hong, W.; Sauer, S.; et al. An integrated view of the methane system in the pockmarks at Vestnesa Ridge, 79 ${ }^{\circ}$ N. Mar. Geol. 2017, 390, 282-300. [CrossRef]

91. Sassen, R.; Roberts, H.H.; Aharon, P.; Larkin, J. Chemosynthetic bacterial mats at cold hydrocarbon seeps, Gulf of Mexico continental slope. Org. Geochem. 1993, 20, 77-89. [CrossRef]

92. Schumacher, D. Hydrocarbon-Induced Alteration of Soils and Sediments. AAPG Mem. 1996, 66, 71-89.

93. King, L.H. Pockmarks on the Scotian Shelf. Geol. Soc. Am. Bull. 1970, 81, 3141. [CrossRef]

94. Duarte, D.; Magalhães, V.H.; Terrinha, P.; Ribeiro, C.; Madureira, P.; Pinheiro, L.M.; Benazzouz, O.; Kim, J.H.; Duarte, H. Identification and characterization of fluid escape structures (pockmarks) in the Estremadura Spur, West Iberian Margin. Mar. Pet. Geol. 2017, 82, 414-423. [CrossRef]

95. Forwick, M.; Baeten, N.J.; Vorren, T.O. Pockmarks in Spitsbergen fjords. Nor. J. Geol. 2009, 89, 65-77.

96. Harrington, P.K. Formation of pockmarks by pore-water escape. Geo-Mar. Lett. 1985, 5, 193-197. [CrossRef]

97. Hovland, M.; Gardner, J.V.; Judd, A.G. The significance of pockmarks to understanding fluid flow processes and geohazards. Geofluids 2010, 2, 127-136. [CrossRef]

98. Kramer, K.; Holler, P.; Herbst, G.; Bratek, A.; Ahmerkamp, S.; Neumann, A.; Bartholoma, A.; van Beusekom, J.E.E.; Holtappels, M.; Winter, C. Abrupt emergence of a large pockmark field in the German Bight, southeastern North Sea. Sci. Rep. 2017, 7, 5150. [CrossRef]

99. Tallobre, C.; Loncke, L.; Bassetti, M.-A.; Giresse, P.; Bayon, G.; Buscail, R.; de Madron, X.D.; Bourrin, F.; Vanhaesebroucke, M.; Sotin, C. Description of a contourite depositional system on the Demerara Plateau: Results from geophysical data and sediment cores. Mar. Geol. 2016, 378, 56-73. [CrossRef]

100. Nickel, J.C.; Primio, R.D.; Kai, M.; Stoddart, D.; Kallmeyer, J. Characterization of microbial activity in pockmark fields of the SW-Barents Sea. Mar. Geol. 2012, 332-334, 152-162. [CrossRef]

101. Van Weering, T.; Jansen, J.; Eisma, D. Acoustic reflection profiles of the Norwegian Channel between Oslo and Bergen. Neth. J. Sea Res. 1973, 6, 241-263. [CrossRef]

102. Attias, E.; Weitemeyer, K.; Minshull, T.A.; Best, A.I.; Sinha, M.; Jegen-Kulcsar, M.; Hölz, S.; Berndt, C. Controlled-source electromagnetic and seismic delineation of subseafloor fluid flow structures in a gas hydrate province, offshore Norway. Geophys. J. Int. 2016, 206, 1093-1110. [CrossRef]

103. Cathles, L.M.; Su, Z.; Chen, D. The physics of gas chimney and pockmark formation, with implications for assessment of seafloor hazards and gas sequestration. Mar. Pet. Geol. 2010, 27, 82-91. [CrossRef]

104. Christodoulou, D.; Papatheodorou, G.; Ferentinos, G.; Masson, M. Active seepage in two contrasting pockmark fields in the Patras and Corinth gulfs, Greece. Geo-Mar. Lett. 2003, 23, 194-199. [CrossRef]

105. Gay, A.; Baltzer, A.; Reynaud, M.; Ehrhold, A.; Fournier, J.; Cordier, C.; Clouet, H.; Migeon, S. Space-time evolution of a large field of pockmarks in the Bay of Concarneau (NW Brittany). Bull. Soc. géol. Fr. 2017, 188. [CrossRef]

106. Ostanin, I.; Anka, Z.; di Primio, R. Role of Faults in Hydrocarbon Leakage in the Hammerfest Basin, SW Barents Sea: Insights from Seismic Data and Numerical Modelling. Geosciences 2017, 7, 28. [CrossRef]

107. Pilcher, R.; Argent, J. Mega-pockmarks and linear pockmark trains on the West African continental margin. Mar. Geol. 2007, 244, 15-32. [CrossRef]

108. Schattner, U.; Lazar, M.; Souza, L.A.P.; Brink, U.T.; Mahiques, M.M. Pockmark asymmetry and seafloor currents in the Santos Basin offshore Brazil. Geo-Mar. Lett. 2016, 36, 457-464. [CrossRef]

109. Szpak, M.T.; Monteys, X.; O’Reilly, S.S.; Lilley, M.K.S.; Scott, G.A.; Hart, K.M.; McCarron, S.G.; Kelleher, B.P. Occurrence, characteristics and formation mechanisms of methane generated micro-pockmarks in Dunmanus Bay, Ireland. Cont. Shelf Res. 2015, 103, 45-59. [CrossRef]

110. Hovland, M. Characteristics of pockmarks in the Norwegian Trench. Mar. Geol. 1981, 39, 103-117. [CrossRef]

111. Rauber, R.M.; Grant, L.O.; Feng, D.; Snider, J.B. The Characteristics and Distribution of Cloud Water over the Mountains of Northern Colorado during Wintertime Storms. Part I: Temporal Variations. J. Appl. Meteorol. 1986, 25, 468-488. [CrossRef]

112. Chand, S.; Mienert, J.; Andreassen, K.; Knies, J.; Plassen, L.; Fotland, B. Gas hydrate stability zone modelling in areas of salt tectonics and pockmarks of the Barents Sea suggests an active hydrocarbon venting system. Mar. Pet. Geol. 2008, 25, 625-636. [CrossRef]

113. Greinert, J.; Lewis, K.B.; Bialas, J.; Pecher, I.A.; Rowden, A.; Bowden, D.A.; De Batist, M.; Linke, P. Methane seepage along the Hikurangi Margin, New Zealand: Overview of studies in 2006 and 2007 and new evidence from visual, bathymetric and hydroacoustic investigations. Mar. Geol. 2010, 272, 6-25. [CrossRef]

114. Hovland, M. Pockmarks and the Recent geology of the central section of the Norwegian Trench. Mar. Geol. 1982, 47, 283-301. [CrossRef]

115. Hovland, M. Gas-induced erosion features in the North Sea. Earth Surf. Process. Landf. 1984, 9, 209-228. [CrossRef]

116. Hovland, M. Large pockmarks, gas-charged sediments and possible clay diapirs in the Skagerrak. Mar. Pet. Geol. 1991, 8, 311-316. [CrossRef]

117. Hovland, M.; Vasshus, S.; Heggland, R. Pockmarks in the Norwegian Trench-some new observations. In Proceedings of the Conference on Gas in Marine Sediments, Varna, Bulgaria, 5-10 September 1996. 
118. Judd, A. Pockmarks in the UK Sector of the North Sea. UK Department of Trade and Industry Strategic Environmental Assessment Technical Report; University of Sunderland: Sunderland, UK, 2001.

119. Ondréas, H.; Olu, K.; Fouquet, Y.; Charlou, J.L.; Gay, A.; Dennielou, B.; Donval, J.P.; Fifis, A.; Nadalig, T.; Cochonat, P.; et al. ROV study of a giant pockmark on the Gabon continental margin. Geo-Mar. Lett. 2005, 25, 281-292. [CrossRef]

120. Masoumi, S.; Reuning, L.; Back, S.; Sandrin, A.; Kukla, P.A. Buried pockmarks on the Top Chalk surface of the Danish North Sea and their potential significance for interpreting palaeocirculation patterns. Int. J. Earth Sci. 2014, 103, 563-578. [CrossRef]

121. Hovland, M. The formation of pockmarks and their potential influence on offshore construction. Doboku Gakkai Ronbunshu 1989, 1987, 131-138.

122. Plaza-Faverola, A.; Bünz, S.; Johnson, J.E.; Chand, S.; Knies, J.; Mienert, J.; Franek, P. Role of tectonic stress in seepage evolution along the gas hydrate-charged Vestnesa Ridge, Fram Strait. Geophys. Res. Lett. 2015, 42, 733-742. [CrossRef]

123. Maia, A.R.; Cartwright, J.; Andersen, E. Shallow plumbing systems inferred from spatial analysis of pockmark arrays. Mar. Pet. Geol. 2016, 77, 865-881. [CrossRef]

124. Sultan, N.; Cochonat, P.; Foucher, J.P.; Mienert, J. Effect of gas hydrates melting on seafloor slope instability. Mar. Geol. 2004, 213, 379-401. [CrossRef]

125. Romeyn, R. Processing and Interpretation of the Svyatogor 2016 High-Resolution P-Cable 3D Seismic Dataset. Investigating the Dynamics of a Sub-Seabed Gas Hydrate System with a Potential Abiotic Methane Source. Master's Thesis, UiT Norges arktiske universitet, Tromsø, Norway, 1 June 2017.

126. Heeschen, K.U.; Tréhu, A.M.; Collier, R.W.; Suess, E.; Rehder, G. Distribution and height of methane bubble plumes on the Cascadia Margin characterized by acoustic imaging. Geophys. Res. Lett. 2003, 30, 1643. [CrossRef]

127. Heggland, R. Gas seepage as an indicator of deeper prospective reservoirs. A study based on exploration 3D seismic data. Mar. Pet. Geol. 1998, 15, 1-9. [CrossRef]

128. Bøe, R.; Rise, L.; Ottesen, D. Elongate depressions on the southern slope of the Norwegian Trench (Skagerrak): Morphology and evolution. Mar. Geol. 1998, 146, 191-203. [CrossRef]

129. Hovland, M. Elongated depressions associated with pockmarks in the Western Slope of the Norwegian Trench. Mar. Geol. 1983, 51, 35-46. [CrossRef]

130. Barsoum, K.; Martera, M.D.; Noguera, A.M. Gas Chimneys in the Nile Delta Slope and Gas Fields Occurrence. In Proceedings of the EAGE Conference on Geology and Petroleum Geology of the Mediterranean and Circum-Mediterranean Basins, St. Julians, Malta, 1-4 October 2000.

131. Brooks, J.M.; Cox, H.B.; Bryant, W.R.; Ii, M.C.K.; Mann, R.G.; Mcdonald, T.J. Association of gas hydrates and oil seepage in the Gulf of Mexico. Org. Geochem. 1986, 10, 221-234. [CrossRef]

132. Paull, C.K.; Iii, W.U.; Holbrook, W.S.; Hill, T.M.; Keaten, R.; Mienert, J.; Haflidason, H.; Johnson, J.E.; Winters, W.J.; Lorenson, T.D. Origin of pockmarks and chimney structures on the flanks of the Storegga Slide, offshore Norway. Geo-Mar. Lett. 2008, $28,43-51$. [CrossRef]

133. Andresen, K.J.; Huuse, M. 'Bulls-eye' pockmarks and polygonal faulting in the Lower Congo Basin: Relative timing and implications for fluid expulsion during shallow burial. Mar. Geol. 2011, 279, 111-127. [CrossRef]

134. Chiu, J.; Tseng, W.; Liu, C. Distribution of gassy sediments and mud volcanoes offshore southwestern Taiwan. Terr. Atmos. Ocean. Sci. 2006, 17, 703-722. [CrossRef]

135. Gay, A.; Lopez, M.; Berndt, C.; Séranne, M. Geological controls on focused fluid flow associated with seafloor seeps in the Lower Congo Basin. Mar. Geol. 2007, 244, 68-92. [CrossRef]

136. Stoll, R.D.; Ewing, J.; Bryan, G.M. Anomalous wave velocities in sediments containing gas hydrates. J. Geophys. Res. 1971, 76, 2090-2094. [CrossRef]

137. Cita, M.B. Prometheus mud breccia, an example of shale diapirism in the eastern Mediterranean Ridge. Ann. Geol. Pays Hell. 1981, 30, 543-570.

138. Cita, M.B. The Mediterranean Ridge as an accretionary prism in collisional context. Mem. Soc. Geol. Ital. 1990, 45. [CrossRef]

139. Cita, M.B.; Woodside, J.M.; Ivanov, M.; Kidd, R.B.; Limonov, A.F. Fluid venting, mud volcanoes and mud diapirs in the Mediterranean Ridge. Rend. Lincei 1994, 5, 159-169. [CrossRef]

140. Somoza, L. Seabed morphology and hydrocarbon seepage in the Gulf of Cádiz mud volcano area: Acoustic imagery, multibeam and ultra-high resolution seismic data. Mar. Geol. 2003, 195, 153-176. [CrossRef]

141. Kopf, A.J. Global methane emission through mud volcanoes and its past and present impact on the Earth's climate. Int. J. Earth Sci. 2003, 92, 493-494. [CrossRef]

142. Kopf, A.J. Significance of Mud Volcanism. Rev. Geophys. 2002, 40, 2-1-2-52. [CrossRef]

143. Dimitrov, L.I. Mud volcanoes-The most important pathway for degassing deeply buried sediments. Earth Sci. Rev. 2002, 59, 49-76. [CrossRef]

144. Hedberg, H.D. Relation of Methane Generation to Undercompacted Shales, Shale Diapirs, and Mud Volcanoes. Annu. Rev. Cell Dev. Biol. 1974, 58, 661-673.

145. Milkov, A.V. Worldwide distribution of submarine mud volcanoes and associated gas hydrates. Mar. Geol. 2000, 167, 29-42. [CrossRef] 
146. Wu, T.; Sahling, H.; Feseker, T.; Rendle-Bühring, R.; Wei, J.; Wintersteller, P.; Marcon, Y.; Pape, T.; Römer, M.; Bohrmann, G. Morphology and activity of the Helgoland Mud Volcano in the Sorokin Trough, northern Black Sea. Mar. Pet. Geol. 2019, 99, 227-236. [CrossRef]

147. Wu, T.; Wei, J.; Liu, S.; Guan, Y.; Zhang, R.; Su, M.; Wang, H.; Zhang, W.; Meng, D.; Liu, B. Characteristics and formation mechanism of seafloor domes on the north-eastern continental slope of the South China Sea. Geol. J. 2018, 55, 1-10. [CrossRef]

148. Hovland, M.; Hill, A.; Stokes, D. The structure and geomorphology of the Dashgil mud volcano, Azerbaijan. Geomorphology 1997, 21, 1-15. [CrossRef]

149. Planke, S.; Svensen, H.; Hovland, M.; Banks, D.A.; Jamtveit, B. Mud and fluid migration in active mud volcanoes in Azerbaijan. Geo-Mar. Lett. 2003, 23, 258-268. [CrossRef]

150. Ojha, C.; Ayyadurai, V.; Nainar, R. Mud volcanoes show gas hydrate potential in India's Andaman Islands. Oil Gas J. 2015, 113, 44-53.

151. Martinelli, G.; Judd, A. Mud volcanoes of Italy. Geol. J. 2004, 39, 49-61. [CrossRef]

152. Mazzini, A.; Svensen, H.; Akhmanov, G.G.; Aloisi, G.; Planke, S.; Malthe-Sørenssen, A.; Istadi, B. Triggering and dynamic evolution of the LUSI mud volcano, Indonesia. Earth Planet. Sci. Lett. 2007, 261, 375-388. [CrossRef]

153. Hovland, M. Hydrocarbon Seeps in Northern Marine Waters: Their Occurrence and Effects. Palaios 1992, 7, 376-382. [CrossRef]

154. Dupré, S.; Buffet, G.; Mascle, J.; Foucher, J.P.; Gauger, S.; Boetius, A.; Marfia, C. High-resolution mapping of large gas emitting mud volcanoes on the Egyptian continental margin (Nile Deep Sea Fan) by AUV surveys. Mar. Geophys. Res. 2009, 29, 275-290. [CrossRef]

155. Shyu, C.T.; Hsu, S.K.; Liu, C.S. Heat flows off Southwest Taiwan: Measurements over mud diapirs and estimated from bottom simulating reflectors. Terr. Atmos. Ocean. Sci. 1998, 9, 795-812. [CrossRef]

156. Sumner, R.H.; Westbrook, G.K. Mud diapirism in front of the Barbados accretionary wedge: The influence of fracture zones and North America-South America plate motions. Mar. Pet. Geol. 2001, 18, 591-613. [CrossRef]

157. Stewart, S.A.; Davies, R.J. Structure and emplacement of mud volcano systems in the South Caspian Basin. Appl. Psychol. 2006, 90, 771-786. [CrossRef]

158. Bouriak, S.; Vanneste, M.; Saoutkine, A. Inferred gas hydrates and clay diapirs near the Storegga Slide on the southern edge of the Vøring Plateau, offshore Norway. Mar. Geol. 2000, 163, 125-148. [CrossRef]

159. Fusi, N.; Kenyon, N.H. Distribution of mud diapirism and other geological structures from long-range sidescan sonar (GLORIA) data, in the Eastern Mediterranean Sea. Mar. Geol. 1996, 132, 21-38. [CrossRef]

160. Aloisi, J.; Wallmann, K.; Haese, R.; Saliège, J.-F. Chemical, biological and hydrological controls on the $14 \mathrm{C}$ content of cold seep carbonate crusts: Numerical modeling and implications for convection at cold seeps. Chem. Geol. 2004, 213, 359-383. [CrossRef]

161. Gemmer, L.; Ings, S.J.; Medvedev, S.; Beaumont, C. Salt tectonics driven by differential sediment loading: Stability analysis and finite-element experiments. Basin Res. 2015, 16, 199-218. [CrossRef]

162. Hudec, M.R.; Jackson, M.P.A. Terra infirma: Understanding salt tectonics. Earth-Sci. Rev. 2007, 82, 1-28. [CrossRef]

163. Karakitsios, V.; Rigakis, N.; Bakopoulos, I. Migration and trapping of the Ionian series hydrocarbons (Epirus, NW Greece). Bull. Geol. Soc. Greece 2001, 34, 1237-1245. [CrossRef]

164. Salazar, J.A.; Knapp, J.H.; Knapp, C.C.; Pyles, D.R. Salt tectonics and Pliocene stratigraphic framework at MC-118, Gulf of Mexico: An integrated approach with application to deep-water confined structures in salt basins. Mar. Pet. Geol. 2014, 50, 51-67. [CrossRef]

165. Gradmann, S.; Hübscher, C.; Ben-Avraham, Z.; Gajewski, D.; Netzeband, G. Salt tectonics off northern Israel. Mar. Pet. Geol. 2005, 22, 597-611. [CrossRef]

166. Gee, M.J.R.; Gawthorpe, R.L. Submarine channels controlled by salt tectonics: Examples from 3D seismic data offshore Angola. Mar. Pet. Geol. 2006, 23, 443-458. [CrossRef]

167. Mohriak, W.; Taiwani, M. Evolution of the Angolan Passive Margin, West Africa, With Emphasis on Post-Salt Structural Styles; American Geophysical Union: Washington, DC, USA, 2013; pp. 129-149.

168. Stewart, S.A.; Coward, M.P. Synthesis of salt tectonics in the southern North Sea, UK. Mar. Pet. Geol. 1995, 12, 457-475. [CrossRef]

169. Buchanan, P.G.; Bishop, D.J.; Hood, D.N. Development of salt-related structures in the Central North Sea: Results from section balancing. Geol. Soc. Lond. Spec. Publ. 1996, 100, 111-128. [CrossRef]

170. Smit, J.; Brun, J.P.; Fort, X.; Cloetingh, S.; Ben-Avraham, Z. Salt tectonics in pull-apart basins with application to the Dead Sea Basin. Tectonophysics 2008, 449, 1-16. [CrossRef]

171. Maillard, A.; Gaullier, V.; Vendeville, B.C.; Odonne, F. Influence of differential compaction above basement steps on salt tectonics in the Ligurian-Provençal Basin, northwest Mediterranean. Mar. Pet. Geol. 2003, 20, 13-27. [CrossRef]

172. Hudec, M.R.; Jackson, M.P.A. Structural segmentation, inversion, and salt tectonics on a passive margin: Evolution of the Inner Kwanza Basin, Angola. Geol. Soc. Am. Bull. 2002, 115, 641. [CrossRef]

173. Larsen, B.D.; Ben-Avraham, Z.; Shulman, H. Fault and salt tectonics in the southern Dead Sea basin. Tectonophysics 2002, 346, 71-90. [CrossRef]

174. Gemmer, L.; Beaumont, C.; Ings, S.J. Dynamic modelling of passive margin salt tectonics: Effects of water loading, sediment properties and sedimentation patterns. Basin Res. 2010, 17, 383-402. [CrossRef]

175. Brun, J.P.; Fort, X. Compressional salt tectonics (Angolan margin). Tectonophysics 2004, 382, 129-150. [CrossRef]

176. Fort, X. Salt tectonics on the Angolan margin, synsedimentary deformation process. AAPG Bull. 2004, 88, 1523-1544. [CrossRef] 
177. Rowan, M.G.; Peel, F.J.; Vendeville, B.C.; Gaullier, V. Salt tectonics at passive margins: Geology versus models—Discussion. Mar. Pet. Geol. 2012, 37, 184-194. [CrossRef]

178. Brun, J.-P.; Fort, X. Salt tectonics at passive margins: Geology versus models. Mar. Pet. Geol. 2011, 28, 1123-1145. [CrossRef]

179. Loncke, L.; Mascle, J.; Parties, F.S. Mud volcanoes, gas chimneys, pockmarks and mounds in the Nile deep-sea fan (Eastern Mediterranean): Geophysical evidences. Mar. Pet. Geol. 2004, 21, 669-689. [CrossRef]

180. Stewart, S.A. Implications of passive salt diapir kinematics for reservoir segmentation by radial and concentric faults. Mar. Pet. Geol. 2006, 23, 843-853. [CrossRef]

181. Urlaub, M.; Talling, P.J.; Zervos, A.; Masson, D. What causes large submarine landslides on low gradient $\left(<2^{\circ}\right)$ continental slopes with slow ( $\sim 0.15 \mathrm{~m} / \mathrm{kyr})$ sediment accumulation? J. Geophys. Res. Solid Earth 2015, 120, 6722-6739. [CrossRef]

182. Zhu, C.; Cheng, S.; Li, Q.; Shan, H.; Lu, J.A.; Shen, Z.; Liu, X.; Jia, Y. Giant Submarine Landslide in the South China Sea: Evidence, Causes, and Implications. J. Mar. Sci. Eng. 2019, 7, 152. [CrossRef]

183. Hesthammer, J.; Fossen, H. Evolution and geometries of gravitational collapse structures with examples from the StatfJord Field, northern North Sea. Mar. Pet. Geol. 1999, 16, 259-281. [CrossRef]

184. Shanmugam, G. The landslide problem. J. Palaeogeogr. 2015, 4, 109-166. [CrossRef]

185. Loon, A.J.V.; Brodzikowski, K. Problems and progress in the research on soft-sediment deformations. Sediment. Geol. 1987, 50, 167-193. [CrossRef]

186. Hampton, M.A.; Lee, H.J.; Locat, J. Submarine landslides. Rev. Geophys. 1996, 34, 33-59. [CrossRef]

187. Locat, J.; Lee, H.J. Submarine landslides: Advances and challenges. Can. Geotech. J. 2002, 39, 193-212. [CrossRef]

188. Masson, D.G.; Harbitz, C.B.; Wynn, R.B.; Pedersen, G.; Løvholt, F. Submarine landslides: Processes, triggers and hazard prediction. Philos. Trans. Math. Phys. Eng. Sci. 2006, 364, 2009-2039. [CrossRef] [PubMed]

189. Pope, E.L.; Talling, P.J.; Urlaub, M.; Hunt, J.E.; Clare, M.A.; Challenor, P. Are large submarine landslides temporally random or do uncertainties in available age constraints make it impossible to tell? Mar. Geol. 2015, 369, 19-33. [CrossRef]

190. Vanneste, M.; Sultan, N.; Garziglia, S.; Forsberg, C.F.; L'Heureux, J.S. Seafloor instabilities and sediment deformation processes: The need for integrated, multi-disciplinary investigations. Mar. Geol. 2014, 352, 183-214. [CrossRef]

191. Zhu, M.; Graham, S.; Pang, X.; Mchargue, T. Characteristics of migrating submarine canyons from the middle Miocene to present: Implications for paleoceanographic circulation, northern South China Sea. Mar. Pet. Geol. 2010, 27, 307-319. [CrossRef]

192. He, Y.; Zhong, G.; Wang, L.; Kuang, Z. Characteristics and occurrence of submarine canyon-associated landslides in the middle of the northern continental slope, South China Sea. Mar. Pet. Geol. 2014, 57, 546-560. [CrossRef]

193. Wang, L.; Wu, S.G.; Li, Q.P.; Wang, D.W.; Fu, S.Y. Architecture and development of a multi-stage Baiyun submarine slide complex in the Pearl River Canyon, northern South China Sea. Geo-Mar. Lett. 2014, 34, 327-343. [CrossRef]

194. Ruano, P.; Bohoyo, F.; Galindo-Zaldívar, J.; Pérez, L.F.; Hernández-Molina, F.J.; Maldonado, A.; García, M.; Medialdea, T. Mass transport processes in the southern Scotia Sea: Evidence of paleoearthquakes. Glob. Planet. Chang. 2014, 123, 374-391. [CrossRef]

195. Tournadour, E.; Mulder, T.; Borgomano, J.; Hanquiez, V.; Ducassou, E.; Gillet, H. Origin and architecture of a Mass Transport Complex on the northwest slope of Little Bahama Bank (Bahamas): Relations between off-bank transport, bottom current sedimentation and submarine landslides. Sediment. Geol. 2015, 317, 9-26. [CrossRef]

196. Ai, F.; Strasser, M.; Preu, B.; Hanebuth, T.J.J.; Krastel, S.; Kopf, A. New constraints on oceanographic vs. seismic control on submarine landslide initiation: A geotechnical approach off Uruguay and northern Argentina. Geo-Mar. Lett. 2014, 34, $399-417$. [CrossRef]

197. Urgeles, R.; Camerlenghi, A. Submarine landslides of the Mediterranean Sea: Trigger mechanisms, dynamics, and frequencymagnitude distribution. J. Geophys. Res. Earth Surf. 2013, 118, 2600-2618. [CrossRef]

198. Sultan, N.; Cochonat, P.; Canals, M.; Cattaneo, A.; Dennielou, B.; Haflidason, H.; Laberg, J.S.; Long, D.; Mienert, J.; Trincardi, F. Triggering mechanisms of slope instability processes and sediment failures on continental margins: A geotechnical approach. Mar. Geol. 2004, 213, 291-321. [CrossRef]

199. Bryn, P.; Berg, K.; Forsberg, C.F.; Solheim, A.; Kvalstad, T.J. Explaining the Storegga Slide. Mar. Pet. Geol. 2005, 22, 11-19. [CrossRef]

200. Kvalstad, T.J.; Andresen, L.; Forsberg, C.F.; Berg, K.; Bryn, P.; Wangen, M. The Storegga slide: Evaluation of triggering sources and slide mechanics. Mar. Pet. Geol. 2005, 22, 245-256. [CrossRef]

201. Katz, O.; Reuven, E.; Aharonov, E. Submarine landslides and fault scarps along the eastern Mediterranean Israeli continental-slope. Mar. Geol. 2015, 369, 100-115. [CrossRef]

202. Lee, H.J.; Chough, S.; Yoon, S. Slope-stability change from late pleistocene to holocene in the Ulleung Basin, East Sea (Japan Sea). Sediment. Geol. 1996, 104, 39-51. [CrossRef]

203. Li, W.; Wu, S.; Völker, D.; Zhao, F.; Mi, L.; Kopf, A. Morphology, seismic characterization and sediment dynamics of the Baiyun Slide Complex on the northern South China Sea margin. J. Geol. Soc. 2014, 171. [CrossRef]

204. Berndt, C.; Costa, S.; Canals, M.; Camerlenghi, A.; Mol, B.D.; Saunders, M. Repeated slope failure linked to fluid migration: The Ana submarine landslide complex, Eivissa Channel, Western Mediterranean Sea. Earth Planet. Sci. Lett. 2012, 319-320, 65-74. [CrossRef]

205. Zhang, M.; Huang, Y.; Bao, Y. The mechanism of shallow submarine landslides triggered by storm surge. Nat. Hazards 2016, 81, 1373-1383. [CrossRef] 
206. Liu, T.; Lu, Y.; Zhou, L.; Yang, X.; Guo, L. Experiment and Analysis of Submarine Landslide Model Caused by Elevated Pore Pressure. J. Mar. Sci. Eng. 2019, 7, 146. [CrossRef]

207. McAdoo, B.G.; Pratson, L.F.; Orange, D.L. Submarine landslide geomorphology, US continental slope. Mar. Geol. 2000, 169, 103-136. [CrossRef]

208. Cartwright, J. Diagenetically induced shear failure of fine-grained sediments and the development of polygonal fault systems. Mar. Pet. Geol. 2011, 28, 1593-1610. [CrossRef]

209. Colón, S.; Audemard, F.A.; Beck, C.; Avila, J.; Padrón, C.; De Batist, M.; Paolini, M.; Leal, A.F.; Van Welden, A. The 1900 Mw 7.6 earthquake offshore north-central Venezuela: Is La Tortuga or San Sebastián the source fault? Mar. Pet. Geol. 2015, 67, 498-511. [CrossRef]

210. Goulty, N.R. Polygonal fault networks in fine-grained sediments-An alternative to the syneresis mechanism. First Break 2001, 19, 69-73. [CrossRef]

211. Tewksbury, B.J.; Hogan, J.P.; Kattenhorn, S.A.; Mehrtens, C.J.; Tarabees, E.A. Polygonal faults in chalk: Insights from extensive exposures of the Khoman Formation, Western Desert, Egypt. Geology 2014, 42, 479-482. [CrossRef]

212. Berndt, C.; Bünz, S.; Mienert, J. Polygonal fault systems on the mid-Norwegian margin: A long-term source for fluid flow. Geol. Soc. Lond. Spec. Publ. 2003, 216, 283-290. [CrossRef]

213. Cartwright, J.; James, D.; Bolton, A. The genesis of polygonal fault systems: A review. Geol. Soc. Lond. Spec. Publ. 2003, 216, 223-243. [CrossRef]

214. Cartwright, J.; Lonergan, L. Seismic expression of layer-bound fault systems of the Eromanga and North Sea Basins. Explor. Geophys. 1997, 28, 323-331. [CrossRef]

215. Cartwright, J.A. Episodic basin-wide hydrofracturing of overpressured Early Cenozoic mudrock sequences in the North Sea Basin. Mar. Pet. Geol. 1994, 11, 587-607. [CrossRef]

216. Cartwright, J.A. Episodic basin-wide fluid expulsion from geopressured shale sequences in the North Sea basin. Geology 1994, 22, 447-450. [CrossRef]

217. Cartwright, J.A.; Lonergan, L. Volumetric contraction during the compaction of mudrocks: A mechanism for the development of regional-scale polygonal fault systems. Basin Res. 1996, 8, 183-193. [CrossRef]

218. Cartwright, J.A.; Dewhurst, D.N. Layer-bound compaction faults in fine-grained sediments. Geol. Soc. Am. Bull. 1998, 110, 1242-1257. [CrossRef]

219. Gay, A.; de Lépinay, B.M.; Ratzov, G.; Jean-Frédéric, L.; Lallemand, S.; Garanti Scientific Team. Seafloor giant polygons associated with underlying polygonal faults in the Caribbean Sea, west off Granada. In Proceedings of the International Meeting of Sedimentologists, Toulouse, France, 10-12 October 2017.

220. Goulty, N.R. Mechanics of layer-bound polygonal faulting in fine-grained sediments. J. Geol. Soc. 2002, 159, 239-246. [CrossRef]

221. Jackson, C.A.L.; Carruthers, D.T.; Mahlo, S.N.; Briggs, O. Can polygonal faults help locate deep-water reservoirs? AAPG Bull. 2014, 98, 1717-1738. [CrossRef]

222. Ostanin, I.; Anka, Z.; di Primio, R.; Bernal, A. Identification of a large Upper Cretaceous polygonal fault network in the Hammerfest basin: Implications on the reactivation of regional faulting and gas leakage dynamics, SW Barents Sea. Mar. Geol. 2012, 332, 109-125. [CrossRef]

223. Seebeck, H.; Tenthorey, E.; Consoli, C.; Nicol, A. Polygonal faulting and seal integrity in the Bonaparte Basin, Australia. Mar. Pet. Geol. 2015, 60, 120-135. [CrossRef]

224. Morgan, D.A.; Cartwright, J.A.; Imbert, P. Perturbation of polygonal fault propagation by buried pockmarks and the implications for the development of polygonal fault systems. Mar. Pet. Geol. 2015, 65, 157-171. [CrossRef]

225. Hale, D.; Groshong, R.H. Conical faults apparent in a 3D seismic image. Interpretation 2014, 2, T1-T11. [CrossRef]

226. Laurent, D.; Gay, A.; Baudon, C.; Berndt, C.; Soliva, R.; Planke, S.; Mourgues, R.; Lacaze, S.; Pauget, F.; Mangue, M.; et al. High-resolution architecture of a polygonal fault interval inferred from geomodel applied to 3D seismic data from the Gjallar Ridge, Vøring Basin, Offshore Norway. Mar. Geol. 2012, 332, 134-151. [CrossRef]

227. Lonergan, L.; Cartwright, J.; Jolly, R. The geometry of polygonal fault systems in Tertiary mudrocks of the North Sea. J. Struct. Geol. 1998, 20, 529-548. [CrossRef]

228. Wrona, T.; Magee, C.; Jackson, C.A.L.; Huuse, M.; Taylor, K.G. Kinematics of Polygonal Fault Systems: Observations from the Northern North Sea. Front. Earth Sci. 2017, 5, 101. [CrossRef]

229. Henriet, J.P.; Batist, M.D.; Verschuren, M. Early fracturing of Palaeogene clays, southernmost North Sea relevance to mechanisms of primary hydrocarbon migration. Gener. Accumul. Prod. Eur. Hydrocarb. Eur. Assoc. Pet. Geosci. Spec. Publ. 1991, 1, $217-227$.

230. Higgs, W.G.; Mcclay, K.R. Analogue sandbox modelling of Miocene extensional faulting in the Outer Moray Firth. Geol. Soc. Lond. Spec. Publ. 1993, 71, 141-162. [CrossRef]

231. Clausen, J.A.; Gabrielsen, R.H.; Reksnes, P.A.; Nysæther, E. Development of intraformational (Oligocene-Miocene) faults in the northern North Sea: Influence of remote stresses and doming of Fennoscandia. J. Struct. Geol. 1999, 21, 1457-1475. [CrossRef]

232. Dewhurst, D.N.; Cartwright, J.A.; Lonergan, L. The development of polygonal fault systems by syneresis of colloidal sediments. Mar. Pet. Geol. 1999, 16, 793-810. [CrossRef]

233. Kumar, P.C.; Naim, F.; Mohanty, S. Seismic expression of polygonal fault systems: An example from North Sea, Dutch Offshore. In Proceedings of the Spg/seg 2016 International Geophysical Conference, Beijing, China, 20-22 April 2016; p. 556. 
234. Kulikowski, D.; Amrouch, K.; Cooke, D.; Gray, M.E. Basement structural architecture and hydrocarbon conduit potential of polygonal faults in the Cooper-Eromanga Basin, Australia. Geophys. Prospect. 2018, 66, 366-396. [CrossRef]

235. Nicol, A.; Walsh, J.J.; Watterson, J.; Nell, P.A.R.; Bretan, P. The geometry, growth and linkage of faults within a polygonal fault system from South Australia. Geol. Soc. Lond. Spec. Publ. 2003, 216, 245-261. [CrossRef]

236. Watterson, J.; Walsh, J.; Nicol, A.; Nell, P.A.R.; Bretan, P.G. Geometry and origin of a polygonal fault system. J. Geol. Soc. 2000, 157, 151-162. [CrossRef]

237. Han, J.; Leng, J.; Wang, Y. Characteristics and genesis of the polygonal fault system in southern slope of the Qiongdongnan Basin, South China Sea. Mar. Pet. Geol. 2016, 70, 163-174. [CrossRef]

238. Li, Y.; Pu, R.; Fan, X.; Li, B. Characteristics and Genesis of the Polygonal Fault System in Beijiao Sag of the Qiongdongnan Basin, the Northern South China Sea. Geotecton. Et Metallog. 2017, 41, 817-828.

239. Sun, Q.; Wu, S.; Lü, F.; Yuan, S. Polygonal faults and their implications for hydrocarbon reservoirs in the southern Qiongdongnan Basin, South China Sea. J. Asian Earth Sci. 2010, 39, 470-479. [CrossRef]

240. Wang, X.; Wu, S.; Yuan, S.; Wang, D.; Ma, Y.; Yao, G.; Gong, Y.; Zhang, G. Geophysical signatures associated with fluid flow and gas hydrate occurrence in a tectonically quiescent sequence, Qiongdongnan Basin, South China Sea. Geofluids 2010, 10, 351-368. [CrossRef]

241. Wang, X.J.; Wu, S.G.; Wang, D.W.; Ma, Y.B.; Yao, G.S.; Gong, Y.H. The role of polygonal faults in fluid migration and gas hydrate reservoir forming in Southeast Hainan Basin. Oil Geophys. Prospect. 2010, 45, 122-128.

242. Yang, T.; Fuliang, L.; Wang, B.; Yang, Z.; Li, L.; Zhang, Q. Characteristics of Polygonal Faults Distribution and Analysis of Its Controlling Factors in Southern Xisha Offshore, South China Sea. Mar. Orig. Pet. Geol. 2017, 22, 84-88.

243. Gay, A.; Lopez, M.; Cochonat, P.; Sermondadaz, G. Polygonal faults-furrows system related to early stages of compaction-upper Miocene to recent sediments of the Lower Congo Basin. Basin Res. 2004, 16, 101-116. [CrossRef]

244. Ma, G.; Lu, H.; Lu, J.A.; Hou, G.; Gong, Y. Polygonal fault in marine sediments and its impact on gas hydrate occurrence. Geol. China 2020, 47, 1-13.

245. Cartwright, J.A.; Dewhurst, D.N. Compaction by syneresis: A mechanism for the development of polygonal fault systems in ultra-fine grained sediments. Ann. Geophys. 1998, 16, 266.

246. Gay, A. Are polygonal faults the keystone for better understanding the timing of fluid migration in sedimentary basins? EPJ Web Conf. 2017, 140. [CrossRef]

247. Hansen, D.M.; Shimeld, J.W.; Williamson, M.A.; Lykke-Andersen, H. Development of a major polygonal fault system in Upper Cretaceous chalk and Cenozoic mudrocks of the Sable Subbasin, Canadian Atlantic margin. Mar. Pet. Geol. 2004, 21, 1205-1219. [CrossRef]

248. Lonergan, L.; Cartwright, J.; Laver, R.; Staffurth, J. Polygonal faulting in the Tertiary of the central North Sea: Implications for reservoir geology. Geol. Soc. Lond. Spec. Publ. 1998, 127, 191-207. [CrossRef]

249. Shin, H.; Santamarina, J.C.; Cartwright, J.A. Contraction-driven shear failure in compacting uncemented sediments. Geology 2008, 36, 931-934. [CrossRef]

250. Shin, H.; Santamarina, J.C.; Cartwright, J.A. Displacement field in contraction-driven faults. J. Geophys. Res. Solid Earth $2010,115$. [CrossRef]

251. Goulty, N.R. Geomechanics of polygonal fault systems: A review. Pet. Geosci. 2009, 14, 389-397. [CrossRef]

252. Kettermann, M.; Urai, J.L.; Vrolijk, P.J. Evolution of structure and permeability of normal faults with clay smear: Insights from water-saturated sandbox models and numerical simulations. J. Geophys. Res. Solid Earth 2017, 122. [CrossRef]

253. Hustoft, S.; Mienert, J.; Bünz, S.; Nouzé, H. High-resolution 3D-seismic data indicate focussed fluid migration pathways above polygonal fault systems of the mid-Norwegian margin. Mar. Geol. 2007, 245, 89-106. [CrossRef]

254. Chen, D.; Wu, S.; Völker, D.; Dong, D.; Shi, H.; Zhao, S.; Zhu, L. Tectonically induced, deep-burial paleo-collapses in the Zhujiang Miocene carbonate platform in the northern South China Sea. Mar. Geol. 2015, 364, 43-52. [CrossRef]

255. Berndt, C. Focused fluid flow in passive continental margins. Philos. Trans. R. Soc. A: Math. Phys. Eng. Sci. 2005, 363, 2855-2871. [CrossRef]

256. Armijo, R.; Meyer, B.; Navarro, S.; King, G.; Barka, A. Asymmetric slip partitioning in the Sea of Marmara pull-apart: A clue to propagation processes of the North Anatolian Fault? Terra Nova 2010, 14, 80-86. [CrossRef]

257. Déverchère, J.; Yelles, K.; Domzig, A.; Lépinay, B.M.D.; Bouillin, J.P.; Gaullier, V.; Bracène, R.; Calais, E.; Savoye, B.; Kherroubi, A. Active thrust faulting offshore Boumerdes, Algeria, and its relations to the $2003 \mathrm{Mw} 6.9$ earthquake. Geophys. Res. Lett. 2005, 32, 319-325. [CrossRef]

258. McHugh, C.M.G.; Seeber, L.; Cormier, M.-H.; Dutton, J.; Cagatay, N.; Polonia, A.; Ryan, W.B.F.; Gorur, N. Submarine earthquake geology along the North Anatolia Fault in the Marmara Sea, Turkey: A model for transform basin sedimentation. Earth Planet. Sci. Lett. 2006, 248, 661-684. [CrossRef]

259. Pavlides, S.; Tsapanos, T.; Zouros, N.; Sboras, S.; Koravos, G.; Chatzipetros, A. Using active fault data for assessing seismic hazard: A case study from NE Aegean sea, Greece. In Proceedings of the Earthquake Geotechnical Engineering Satellite Conference: XVIIth International Conference on Soil Mechanics \& Geotechnical Engineering, Alexandria, Egypt, 2-3 October 2009.

260. Brown, K.M.; Tryon, M.D.; Deshon, H.R.; Dorman, L.R.M.; Schwartz, S.Y. Correlated transient fluid pulsing and seismic tremor in the Costa Rica subduction zone. Earth Planet. Sci. Lett. 2005, 238, 189-203. [CrossRef] 
261. Barın, B.; Okay, S.; Çifçi, G.; Dondurur, D.; Cormier, M.H.; Sorlien, C.; Meriç İlkimen, E. The central branch of the North Anatolian Fault In The Southern Marmara Sea: Evidence for a distributed, Holocene-active fault system. In Proceedings of the EGU General Assembly Conference, Vienna, Austria, 12-17 April 2015.

262. Chevalier, N.; Birgel, D.; Lopezgarcia, P.; Taphanel, M.H.; Bouloubassi, I. Evidence for microbial methane oxidation at cold seeps along the main active fault in the Marmara Sea. In Proceedings of the EGU General Assembly Conference, Vienna, Austria, 2-7 May 2010.

263. Zitter, T.A.C.; Henry, P.; Aloisi, G.; Delaygue, G.; Çagatay, M.N.; De, L.B.; Al, S.M.; Fornacciari, F.; Tesmer, M.; Pekdeger, A. Cold seeps along the main Marmara Fault in the Sea of Marmara (Turkey). Deep Sea Res. Part I Oceanogr. Res. Pap. 2008, 55, 552-570. [CrossRef]

264. Géli, L.; Henry, P.; Zitter, T.; Dupré, S.; Tryon, M.; Çağatay, M.N.; Lépinay, B.M.D.; Pichon, X.L.; Şengör, A.M.C.; Görür, N. Gas emissions and active tectonics within the submerged section of the North Anatolian Fault zone in the Sea of Marmara. Earth Planet. Sci. Lett. 2008, 274, 34-39. [CrossRef]

265. Kuşçu, İ.; Okamura, M.; Matsuoka, H.; Gökaşan, E.; Awata, Y.; Tur, H.; Şimşek, M.; Keçer, M. Seafloor gas seeps and sediment failures triggered by the August 17, 1999 earthquake in the Eastern part of the Gulf of İzmit, Sea of Marmara, NW Turkey. Mar. Geol. 2005, 215, 193-214. [CrossRef]

266. Le Pichon, X.; Şengör, A.M.C.; Demirbağ, E.; Rangin, C.; İmren, C.; Armijo, R.; Görür, N.; Çağatay, N.; Mercier de Lepinay, B.; Meyer, B.; et al. The active Main Marmara Fault. Earth Planet. Sci. Lett. 2001, 192, 595-616. [CrossRef]

267. Okay, A.I.; Kaşlılar-Özcan, A.; İmren, C.; Boztepe-Güney, A.; Demirbağ, E.; Kuşçu, İ. Active faults and evolving strike-slip basins in the Marmara Sea, northwest Turkey: A multichannel seismic reflection study. Tectonophysics 2000, 321, 189-218. [CrossRef]

268. Okay, A.I.; Demirbağ, E.; Kurt, H.; Okay, N.; Kuş̧̧u, İ. An active, deep marine strike-slip basin along the North Anatolian fault in Turkey. Tectonics 1999, 18, 129-147. [CrossRef]

269. Pellegrini, C.; Marchese, F.; Savini, A.; Bistacchi, A. Active normal fault network of the Apulian Ridge (Eastern Mediterranean Sea) imaged by multibeam bathymetry and seismic data. In Proceedings of the EGU General Assembly Conference, Vienna, Austria, 17-22 April 2016.

270. Bistacchi, A.; Pellegrini, C.; Savini, A.; Marchese, F. 3D modelling of the active normal fault network in the Apulian Ridge (Eastern Mediterranean Sea): Integration of seismic and bathymetric data with implicit surface methods. In Proceedings of the EGU General Assembly Conference, Vienna, Austria, 17-22 April 2016.

271. Taymaz, T.; Jackson, J.; Mckenzie, D. Active tectonics of the north and central Aegean Sea. Geophys. J. Int. 2010, 106, 433-490. [CrossRef]

272. Itoh, Y.; Tsutsumi, H.; Yamamoto, H.; Arato, H. Active right-lateral strike-slip fault zone along the southern margin of the Japan Sea. Tectonophysics 2002, 351, 301-314. [CrossRef]

273. Henry, P.; Lallemant, S.; Nakamura, K.I.; Tsunogai, U.; Mazzotti, S.; Kobayashi, K. Surface expression of fluid venting at the toe of the Nankai wedge and implications for flow paths. Mar. Geol. 2002, 187, 119-143. [CrossRef]

274. Pichon, X.L.; Kobayashi, K.; Crew, K.N.S. Fluid venting activity within the eastern Nankai trough accretionary wedge: A summary of the 1989 Kaiko-Nankai results. Earth Planet. Sci. Lett. 1992, 109, 303-318. [CrossRef] 